\title{
Impact of different Asian source regions on the composition of the Asian monsoon anticyclone and of the extratropical lowermost stratosphere
}

\author{
B. Vogel, G. Günther, R. Müller, J.-U. Grooß, and M. Riese \\ Forschungszentrum Jülich, Institute of Energy and Climate Research - Stratosphere (IEK-7), Jülich, Germany \\ Correspondence to: B. Vogel (b.vogel@fz-juelich.de)
}

Received: 10 February 2015 - Published in Atmos. Chem. Phys. Discuss.: 2 April 2015

Revised: 5 October 2015 - Accepted: 23 October 2015 - Published: 10 December 2015

\begin{abstract}
The impact of different boundary layer source regions in Asia on the chemical composition of the Asian monsoon anticyclone, considering its intraseasonal variability in 2012, is analysed by simulations of the Chemical Lagrangian Model of the Stratosphere (CLaMS) using artificial emission tracers. The horizontal distribution of simulated $\mathrm{CO}, \mathrm{O}_{3}$, and artificial emission tracers for India/China are in good agreement with patterns found in satellite measurements of $\mathrm{O}_{3}$ and $\mathrm{CO}$ by the Aura Microwave Limb Sounder (MLS). Using in addition, correlations of artificial emission tracers with potential vorticity demonstrates that the emission tracer for India/China is a very good proxy for spatial distribution of trace gases within the Asian monsoon anticyclone. The Asian monsoon anticyclone constitutes a horizontal transport barrier for emission tracers and is highly variable in location and shape. From the end of June to early August, a northward movement of the anticyclone and, during September, a strong broadening of the spatial distribution of the emission tracer for India/China towards the tropics are found. In addition to the change of the location of the anticyclone, the contribution of different boundary source regions to the composition of the Asian monsoon anticyclone in the upper troposphere strongly depends on its intraseasonal variability and is therefore more complex than hitherto believed. The largest contributions to the composition of the air mass in the anticyclone are found from northern India and Southeast Asia at a potential temperature of $380 \mathrm{~K}$. In the early (midJune to mid-July) and late (September) period of the 2012 monsoon season, contributions of emissions from Southeast Asia are highest; in the intervening period (early August), emissions from northern India have the largest impact. Our findings show that the temporal variation of the contribution
\end{abstract}

of different convective regions is imprinted in the chemical composition of the Asian monsoon anticyclone.

Air masses originating in Southeast Asia are found both within and outside of the Asian monsoon anticyclone because these air masses experience, in addition to transport within the anticyclone, upward transport at the southeastern flank of the anticyclone and in the tropics. Subsequently, isentropic poleward transport of these air masses occurs at around $380 \mathrm{~K}$ with the result that the extratropical lowermost stratosphere in the Northern Hemisphere is flooded by the end of September with air masses originating in Southeast Asia. Even after the breakup of the anticyclonic circulation (around the end of September), significant contributions of air masses originating in India/China are still found in the upper troposphere over Asia. Our results demonstrate that emissions from India, China, and Southeast Asia have a significant impact on the chemical composition of the lowermost stratosphere of the Northern Hemisphere, in particular at the end of the monsoon season in September/October 2012.

\section{Introduction}

The Asian summer monsoon circulation is an important global circulation system in northern summer associated with strong upward transport of tropospheric source gases into the upper troposphere and lower stratosphere (UTLS) region (e.g. Li et al., 2005; Randel and Park, 2006; Park et al., 2007, 2008, 2009). Satellite measurements show that tropospheric trace gases such as water vapour $\left(\mathrm{H}_{2} \mathrm{O}\right)$, carbon monoxide $(\mathrm{CO})$, nitrogen oxides $\left(\mathrm{NO}_{\mathrm{x}}\right)$, peroxy- 
acetyl nitrate (PAN), hydrogen cyanide (HCN), and aerosol are confined by the strong anticyclonic circulation in the UTLS and therefore are isolated from the surrounding air (Rosenlof et al., 1997; Jackson et al., 1998; Park et al., 2004, 2008; Li et al., 2005; Xiong et al., 2009; Randel et al., 2010; Vernier et al., 2011; Bourassa et al., 2012; Fadnavis et al., 2013, 2014). In contrast, stratospheric trace gases such as $\mathrm{O}_{3}, \mathrm{HNO}_{3}$, or $\mathrm{HCl}$ show low concentrations in the anticyclone (Randel and Park, 2006; Park et al., 2008; Liu et al., 2009; Konopka et al., 2010). In general, the Asian monsoon circulation is believed to provide an effective pathway for water vapour and pollutants to the lower stratosphere of the Northern Hemisphere (Bian et al., 2012; Ploeger et al., 2013; Vogel et al., 2014; Uma et al., 2014). The mechanisms for possible transport into the lowermost stratosphere are subjects of a longstanding debate (Dethof et al., 1999; Park et al., 2009; Randel et al., 2010; Bourassa et al., 2012; Fairlie et al., 2014; Fromm et al., 2014; Vogel et al., 2014).

Increasing stratospheric water vapour has a significant influence on the climate system (e.g. Forster and Shine, 1999; Shindell, 2001; Smith et al., 2001; Forster and Shine, 2002; Vogel et al., 2012); in particular the variability of water vapour in the lower stratosphere is an important driver of surface climate change (e.g. Solomon et al., 2010; Riese et al., 2012). In addition, increasing stratospheric water vapour plays a crucial role in stratospheric chemistry (e.g. KirkDavidoff et al., 1999; Dvortsov and Solomon, 2001; Vogel et al., 2011a). Therefore, it is important to understand transport processes from the Asian monsoon region into the global lower stratosphere.

Moreover, the contribution of different boundary source regions in Asia to the chemical composition of the Asian monsoon anticyclone (e.g. Li et al., 2005; Park et al., 2009; Chen et al., 2012; Bergman et al., 2013; Fadnavis et al., 2014) is currently discussed. Chen et al. (2012) found that most impact at tropopause heights is from emissions originating in the tropical Western Pacific region and the South China Sea, while Bergman et al. (2013) found that air masses originating at the Tibetan Plateau and in India are most important at $100 \mathrm{hPa}$. Simulations with a chemistry transport model by Park et al. (2009) show that the main surface sources of CO in the Asian monsoon anticyclone are from India and Southeast Asia, whereby the weak contribution of air masses originating from the Tibetan Plateau in their analysis is due to the lack of significant surface emissions of $\mathrm{CO}$ in this region in their model simulations. Further, air masses from northeast India and southwest China uplifted at the eastern side of the anticyclone could also contribute to the chemical composition of the Asian monsoon anticyclone (Li et al., 2005).

In addition to the impact on the contribution of the Asian monsoon anticyclone, deep convection at the eastern/southeastern side of the Asian monsoon anticyclone is discussed as a pathway for transport of tropospheric air directly into the lower stratosphere by direct convective injec- tion (Rosenlof et al., 1997; Park et al., 2007, 2008; Chen et al., 2012). However, the impact of this transport mechanism on the chemical composition of the lower stratosphere has not been isolated from the exchange between the troposphere and the stratosphere associated with the large-scale Brewer-Dobson circulation (Gettelman et al., 2004; Bannister et al., 2004).

The monsoon and the associated seasonal change of wind and rainfall is characterized by prolonged periods of dry and wet conditions in the range of 2-3 weeks. Extended periods with enhanced precipitation (wet spells) characterize active conditions, while dry spells represent periods when a break in monsoon activity occurs (Goswami, 2012, and references therein). The active and break phases are manifestations of the superposition of large-scale northward-moving 30-to-60day oscillations and small-scale westward-propagating 10to-20-day variations; however, details of this variability are far from being well understood (Goswami, 2012, and references therein). This intraseasonal variability of the monsoon is associated with the strength of the Asian monsoon anticyclone in the UTLS (Goswami, 2012). Further, the evolution over the monsoon season of the anticyclone is characterized by large variability in its extent, strength, and location (e.g. Randel and Park, 2006). Garny and Randel (2013) found that the temporal variability of the strength of the anticyclone, as diagnosed by low areas of potential vorticity $(\mathrm{PV})$, is driven by the variability in convection with a period of 30-40 days. Also, splittings of the Asian monsoon anticyclone into two separate smaller anticyclones frequently occur each year (e.g. Garny and Randel, 2013).

In this paper, we investigate the following main question: what is the impact of different boundary layer source regions in Asia on the composition of air in the Asian monsoon anticyclone 2012 considering the intraseasonal variability of the anticyclone? Further, we analyse how both boundary layer source regions in Asia and the Asian monsoon anticyclone affect the chemical composition of the lowermost stratosphere.

Summer 2012 is a good example for average monsoon conditions. The rainfall in India was medium based on the rainfall data set of 306 rain gauges in India provided by the Indian Institute of Tropical Meteorology in Pune, India ${ }^{1}$. A strong relation between rainfall (droughts or floods) during the Indian summer monsoon to El Niño and La Niña events has been established (e. g. Webster et al., 1998; Kumar et al., 2006). In summer 2012 neutral conditions for the El Niño/Southern Oscillation (ENSO) occurred according to the Oceanic Niño Index ${ }^{2}$.

To answer our question, we performed simulations with the three-dimensional Chemical Lagrangian Model of the Stratosphere (CLaMS) (McKenna et al., 2002b, a; Konopka

\footnotetext{
${ }^{1}$ see e.g. http://www.tropmet.res.in/ kolli/mol/Monsoon/ Historical/air.html

${ }^{2}$ see e.g. http://ggweather.com/enso/oni.htm
} 
et al., 2012, and references therein). The paper is organized as follows: Sect. 2 describes the CLaMS simulations and the use of inert artificial tracers of air mass origin to mark boundary layer source regions. In Sect. 3, the evolution of the Asian monsoon anticyclone is described and CLaMS results are compared with measurements from the Aura Microwave Limb Sounder (MLS). Further, the impact of different emission tracers on the composition of the anticyclone is calculated for the entire 2012 monsoon season. Our results are discussed in Sect. 4 and the conclusions are given in Sect. 5.

\section{The Chemical Lagrangian Model of the Stratosphere}

\subsection{Model description}

Model simulations were performed using the threedimensional chemistry transport model CLaMS that was originally developed for the stratosphere (e.g. McKenna et al., 2002b, a; Grooß et al., 2005; Grooß and Müller, 2007) and extended to the troposphere (Konopka et al., 2010, 2012; Pommrich et al., 2014, and references therein). It was shown in previous studies that CLaMS is very well suited to simulate strong tracer gradients of chemical species in regions where transport barriers exist like the polar vortex (e.g. Günther et al., 2008; Vogel et al., 2008), the extratropical tropopause, and in the vicinity of the jet streams (e.g. Pan et al., 2006; Konopka et al., 2010; Vogel et al., 2011b; Konopka and Pan, 2012).

CLaMS is based on a Lagrangian formulation of tracer transport and considers an ensemble of air parcels on a timedependent irregular grid that is transported by use of threedimensional trajectories. The irreversible part of transport, i.e. mixing, is controlled by the local horizontal strain and vertical shear rates with mixing parameters deduced from observations (Konopka et al., 2010, and references therein). Here, we present results of global CLaMS simulations that cover an altitude range from the surface up to $900 \mathrm{~K}$ potential temperature $(\approx 37 \mathrm{~km}$ altitude) with a horizontal resolution of $100 \mathrm{~km}$ and a maximum vertical resolution of approximately $400 \mathrm{~m}$ at the tropopause. The horizontal winds are taken from the ERA-Interim reanalysis (Dee et al., 2011) provided by the European Centre for Medium-Range Weather Forecasts (ECMWF). In this data set, changes are implemented to improve deep and mid-level convection in ERA-Interim data in contrast to previous reanalysis data (Dee et al., 2011).

Mixing parameter, vertical coordinate, and the crossisentropic velocity of the model follow the model set-up described by Konopka et al. (2012). Convection in CLaMS is represented by vertical velocities in ERA-Interim reanalysis data. CLaMS employs a hybrid coordinate $(\zeta)$, which transforms from a strictly isentropic coordinate $\Theta$ to a pressurebased coordinate system (for more details see Pommrich et al., 2014).
For this study, the CLaMS simulation includes full stratospheric chemistry (Grooß et al., 2014; Sander et al., 2011) and was initialized on 1 May 2012 based on data from AURA-MLS version 3.3 (Livesey et al., 2011) and ACE-FTS version 3.0 and on results of a multi-annual CLaMS simulation started on 1 October 2001 (Konopka et al., 2010). Global $\mathrm{O}_{3}, \mathrm{CO}, \mathrm{H}_{2} \mathrm{O}, \mathrm{HCl}$, and $\mathrm{N}_{2} \mathrm{O}$ fields are derived from MLS data within \pm 2.5 days, while the trajectory-determined synoptic locations have been composed to a $2^{\circ} \times 6^{\circ}$ (latitudelongitude) grid. Below $\zeta=350 \mathrm{~K}$ (equal to $\Theta=350 \mathrm{~K}$ ), these species were taken from the CLaMS multi-annual simulation with a linear transition between $\zeta=350$ and $400 \mathrm{~K}$ (equal to $\Theta=350-400 \mathrm{~K}$ ). $\mathrm{CO}_{2}$ is initialized from this simulation within the whole vertical domain.

The initialization of $\mathrm{CH}_{4}, \mathrm{NO}_{y}, \mathrm{CFC}-11$, and CFC-12 was derived from $\mathrm{N}_{2} \mathrm{O}$ using correlation fits for different latitude bins derived from ACE-FTS version 3.0 data between April and August 2010 following Grooß et al. (2014). The remaining species and the initial partitioning of the chemical families were taken from correlations and the Mainz 2-D model as described by Grooß et al. (2014). At the upper boundary (900 K potential temperature) AURA-MLS and ACE-FTS measurements and tracer-tracer correlations were used similarly as for the initialization (see above). $\mathrm{CO}$ values at the upper boundary were taken from MLS V3.3 data.

At the lower boundary (surface), $\mathrm{O}_{3}$ is set to a constant tropospheric value of $4.8 \times 10^{-8}$ volume mixing ratio representing the ozone mixing ratio at $5 \mathrm{~km}$ (Brasseur and Solomon, 2005 , p. 619). ECMWF water vapour is used in lower model levels. Lower boundary conditions for $\mathrm{CO}$ and $\mathrm{CH}_{4}$ are derived from AIRS (Atmospheric Infrared Sounder) version 6 satellite measurements following the approach described by Pommrich et al. (2014).

\subsubsection{Emission tracers}

The aim of our study is to analyse transport pathways of air masses from boundary layer sources to the Asian monsoon anticyclone and subsequently transport of these air masses into the extratropical lowermost stratosphere. Threedimensional CLaMS simulations were performed to include both the advective transport and the irreversible part of transport, namely mixing. The use of artificial tracers in CLaMS that mark particular regions in the atmosphere allows the origin of air masses, the pathways, and the transport times to be quantified (Günther et al., 2008; Vogel et al., 2011a).

Here, inert artificial tracers of air mass origin, hereafter referred to as "emission tracers", are introduced that mark globally all land masses in the Earth's boundary layer $(\approx 2$ $3 \mathrm{~km}$ above surface following orography corresponding to $\zeta<120 \mathrm{~K}$ ) and thus represent regionally different boundary layer sources regions. Figure 1 shows the geographic locations defined for all 13 emission tracers (red boxes). The latitude and longitude range of each box that represents one emission tracer is listed in Table 1. Further, the 


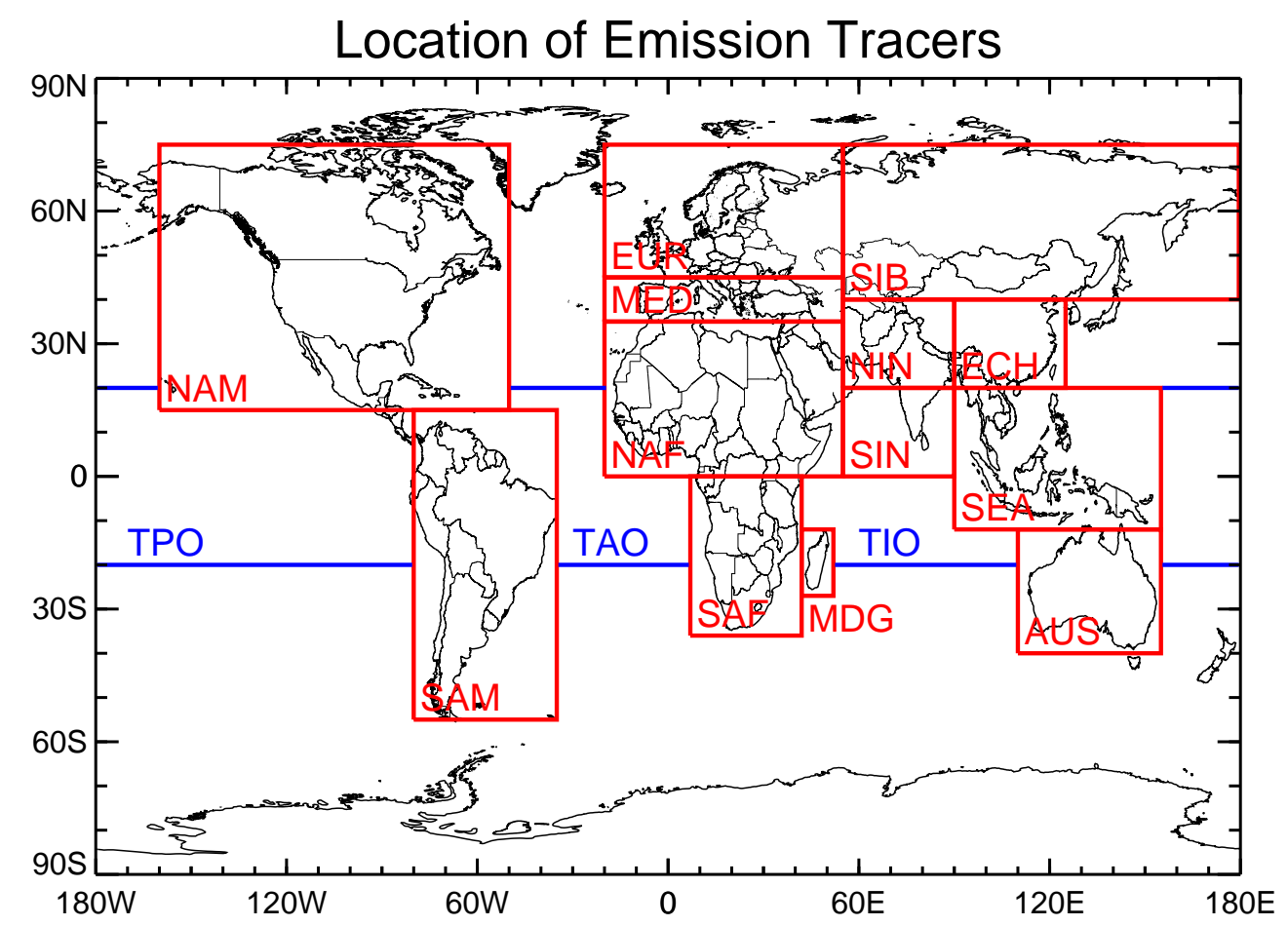

Figure 1. Global geographic location of artificial boundary layer source regions in the CLaMS model, also referred to as "emission tracers". The latitude and longitude range for each emission tracer is listed in Table 1.

remaining tropical regions $\left(20^{\circ} \mathrm{S}-20^{\circ} \mathrm{N}\right)$ over the oceans are also marked by artificial tracers (TPO is Tropical Pacific Ocean, TAO is Tropical Atlantic Ocean, TIO is Tropical Indian Ocean) as indicated by blue lines in Fig. 1. Boundary layer regions not considered by the defined emissions tracers listed in Table 1 are summarized in an emission tracer for the background. As we are particularly interested in the contributions of different boundary layer source regions in Asia to the composition of air within the Asian monsoon anticyclone, the regions defining emission source regions in Asia are better resolved than in regions elsewhere. The separation in different regions in Asia is chosen to separate regions that are currently discussed in the literature as possible source regions (see Sect. 1). The most important regions for our study are northern India (NIN), southern India (SIN), eastern China (ECH), and Southeast Asia (SEA). To discuss the CLaMS results, the percentages of emission tracers for NIN, SIN, and ECH are sometimes summarized in one emission tracer referred to as "India/China" (In$\mathrm{dia} / \mathrm{China}=\mathrm{NIN}+\mathrm{SIN}+\mathrm{ECH})$.

The artificial emission tracers in CLaMS are designed to identify possible boundary source regions in Asia that could contribute to the composition of the Asian monsoon anticyclone in a particular monsoon season, here as a case study for the year 2012. Every $24 \mathrm{~h}$ (time step for mixing in CLaMS), air masses in the model boundary layer are marked by the different emission tracers, i.e. the emission tracer for NIN of an air parcel in the boundary layer over northern India is set equal to $1(\mathrm{NIN}=1)$. If an air parcel has left the model boundary layer over northern India, the value of the emission tracer for NIN $(=1)$ is transported like a chemical tracer to other regions of the free troposphere or stratosphere. Successive mixing processes between air masses from northern India with air masses originating in other regions of the atmosphere (here NIN $=0$ ) during the course of the simulation yield values of NIN differing from the initial distribution (NIN $=1$ or NIN $=0$ ). Therefore, the value of the individual emission tracer counts the percentage of an air masses that originated in the specific boundary layer region since 1 May 2012 considering advection and mixing processes.

\section{Results}

\subsection{Evolution of Asian monsoon anticyclone 2012}

The spatio-temporal evolution of the Asian monsoon anticyclone in summer 2012 is inferred from threedimensional CLaMS simulations using the abovementioned emission tracers for Asia. The CLaMS simulation starts on 1 May 2012 before the formation of the Asian monsoon anticyclone begins during June and ends late October after the breakup of the anticyclone. Deep convection (represented in CLaMS by vertical velocities in ERA-Interim reanalysis data; see Sect. 2.1) leads to strong upward transport of emission tracers from source regions in Asia within the Asian 
Table 1. Latitude and longitude range of artificial boundary layer sources in the CLaMS model, also referred to as "emission tracers". The geographic position of each emission tracer is shown in Fig. 1.

\begin{tabular}{lll}
\hline Emission tracer & Latitude & Longitude \\
\hline Northern India (NIN) & $20-40^{\circ} \mathrm{N}$ & $55-90^{\circ} \mathrm{E}$ \\
Southern India (SIN) & $0-20^{\circ} \mathrm{N}$ & $55-90^{\circ} \mathrm{E}$ \\
Eastern China (ECH) & $20-40^{\circ} \mathrm{N}$ & $90-125^{\circ} \mathrm{E}$ \\
Southeast Asia (SEA) & $12^{\circ} \mathrm{S}-20^{\circ} \mathrm{N}$ & $90-155^{\circ} \mathrm{E}$ \\
Siberia (SIB) & $40-75^{\circ} \mathrm{N}$ & $55-180^{\circ} \mathrm{E}$ \\
Europe (EUR) & $45-75^{\circ} \mathrm{N}$ & $20^{\circ} \mathrm{W}-55^{\circ} \mathrm{E}$ \\
Mediterranean (MED) & $35-45^{\circ} \mathrm{N}$ & $20^{\circ} \mathrm{W}-55^{\circ} \mathrm{E}$ \\
Northern Africa (NAF) & $0-35^{\circ} \mathrm{N}$ & $20^{\circ} \mathrm{W}-55^{\circ} \mathrm{E}$ \\
Southern Africa (SAF) & $36^{\circ} \mathrm{S}-0^{\circ} \mathrm{N}$ & $7-42^{\circ} \mathrm{E}$ \\
Madagascar (MDG) & $27-12^{\circ} \mathrm{S}$ & $42-52^{\circ} \mathrm{E}$ \\
Australia (AUS) & $40-12^{\circ} \mathrm{S}$ & $110-155^{\circ} \mathrm{E}$ \\
North America (NAM) & $15-75^{\circ} \mathrm{N}$ & $160-50^{\circ} \mathrm{W}$ \\
South America (SAM) & $55^{\circ} \mathrm{S}-15^{\circ} \mathrm{N}$ & $80-35^{\circ} \mathrm{W}$ \\
\hline Tropical Pacific Ocean (TPO) & $20^{\circ} \mathrm{S}-20^{\circ} \mathrm{N}$ & see Fig. 1 \\
Tropical Atlantic Ocean (TAO) & $20^{\circ} \mathrm{S}-20^{\circ} \mathrm{N}$ & see Fig. 1 \\
Tropical Indian Ocean (TIO) & $20^{\circ} \mathrm{S}-20^{\circ} \mathrm{N}$ & see Fig. 1 \\
\hline
\end{tabular}

monsoon anticyclone. Our simulation confirms that the extent, strength, and location of the anticyclone is highly variable (e.g. Annamalai and Slingo, 2001; Randel and Park, 2006; Garny and Randel, 2013). In particular, the location and the shape of the anticyclone change from day to day, which is demonstrated in the following.

Because the Asian monsoon anticyclone is characterized by low PV, the horizontal distributions of the emission tracer for India/China in comparison to the horizontal distribution of $\mathrm{PV}$ is analysed at $380 \mathrm{~K}$ potential temperature $(\approx 16 \mathrm{~km})$ (see Figs. 2 and 3). The level of $380 \mathrm{~K}$ potential temperature is located within the Asian monsoon anticyclone just below the thermal tropopause. To discuss the spatio-temporal evolution of the Asian monsoon anticyclone, 6 days are selected that reflect typical situations of the evolution of the Asian monsoon anticyclone. 1 July 2012 shows conditions at the beginning of the evolution of the Asian monsoon (early phase); here the anticyclone is centred over Tibet. 28 July, 2 August, and 8 August 2012 are days in the mid-phase of the monsoon season, when a strong asymmetric anticyclone, a symmetric anticyclone centred over Iran, and an anticyclone split into two smaller anticyclones are found. Conditions during the late phase of the monsoon are shown for 12 September 2012. The situation after the breakup of the anticyclone occurring at the end of September is shown using the example of 7 October 2012.

On 1 July 2012 (Fig. 2, top), the anticyclone is centred over Tibet. The northern flank of the anticyclone border on the subtropical westerly jet and the southern flank to the equatorial easterly jet. In our study, the region of strongest gradients in the horizontal distribution of emission tracers from Asia represent the edge of the anticyclone at $380 \mathrm{~K}$.
A value of 4.5 PVU (thick white line) is introduced, which is in agreement with the upper limit of the PV values derived by Ploeger et al. (2015) to mark the transport barrier for the 2012 Asian monsoon anticyclone at $380 \mathrm{~K}$ (for more details see Sect. 3.2.1). Filaments consisting of air masses characterized by low PV values ( $<4.5 \mathrm{PVU})$ and enhanced emissions from India/China occur both at the western and eastern flank of the anticyclone.

On 28 July 2012 (Fig. 2, second row), the horizontal distribution of high percentages of emission tracers for India/China shows an elongated structure with maxima at its two endpoints located over northeastern Africa and southeastern China (red). The shape of the PV isoline of 4.5 PVU includes two anticyclones situated close together.

After 28 July 2012, the western peak is transported eastwards and the eastern peak moves westwards and both peaks merge in one location in early August. On 2 August 2012 (see Fig. 2, third row), the anticyclone again has a more symmetric shape and is centred over Iran and Afghanistan. The spatial distribution of emission tracers for India/China shows two regions with maximum values: one in the core of the anticyclone over Iran and Afghanistan and a smaller one within the anticyclone farther northeast over China. This pattern is a remnant of the elongated structure found in the distribution of emission tracers for India/China on 28 July 2012 caused by the double peak structure of the Asian monsoon anticyclone. This small-scale structure found in the horizontal distribution of emission tracers for India/China is also evident in the spatial distribution of low PV values. On 8 August 2012 (see Fig. 2, bottom), the Asian monsoon anticyclone is split into two smaller anticyclones: one centred over the northern Middle East (Iraq/Iran) and a second one over eastern China.

In the late phase of the Asian monsoon anticyclone, on 12 September 2012, the spatial distribution of the emission tracer for India/China is shifted towards the tropics compared to the mid-phase as shown in Fig. 3 (top).

In 2012, the breakup of the Asian monsoon anticyclone occurred in late September. Figure 3 (bottom) shows the spatial distribution of the emission tracers for India/China at $380 \mathrm{~K}$ after the breakup on 7 October 2012. The breakup of the anticyclone or the disappearance of the transport barrier goes along with the spread of the emission tracers for India/China at $380 \mathrm{~K}$ within the mid-latitudes of the Northern Hemisphere and in the tropics. High percentages of the emission tracers for India/China are found over the Pacific Ocean and over the east coast of North America along the subtropical westerly jet and in filaments separated at the northeast flank from the Asian monsoon anticyclone (Vogel et al., 2014). In addition, air masses originating in the boundary layer in India/China could penetrate into the upwelling in the deep branch of the Brewer-Dobson circulation and thus could be transported further up into the stratosphere. 

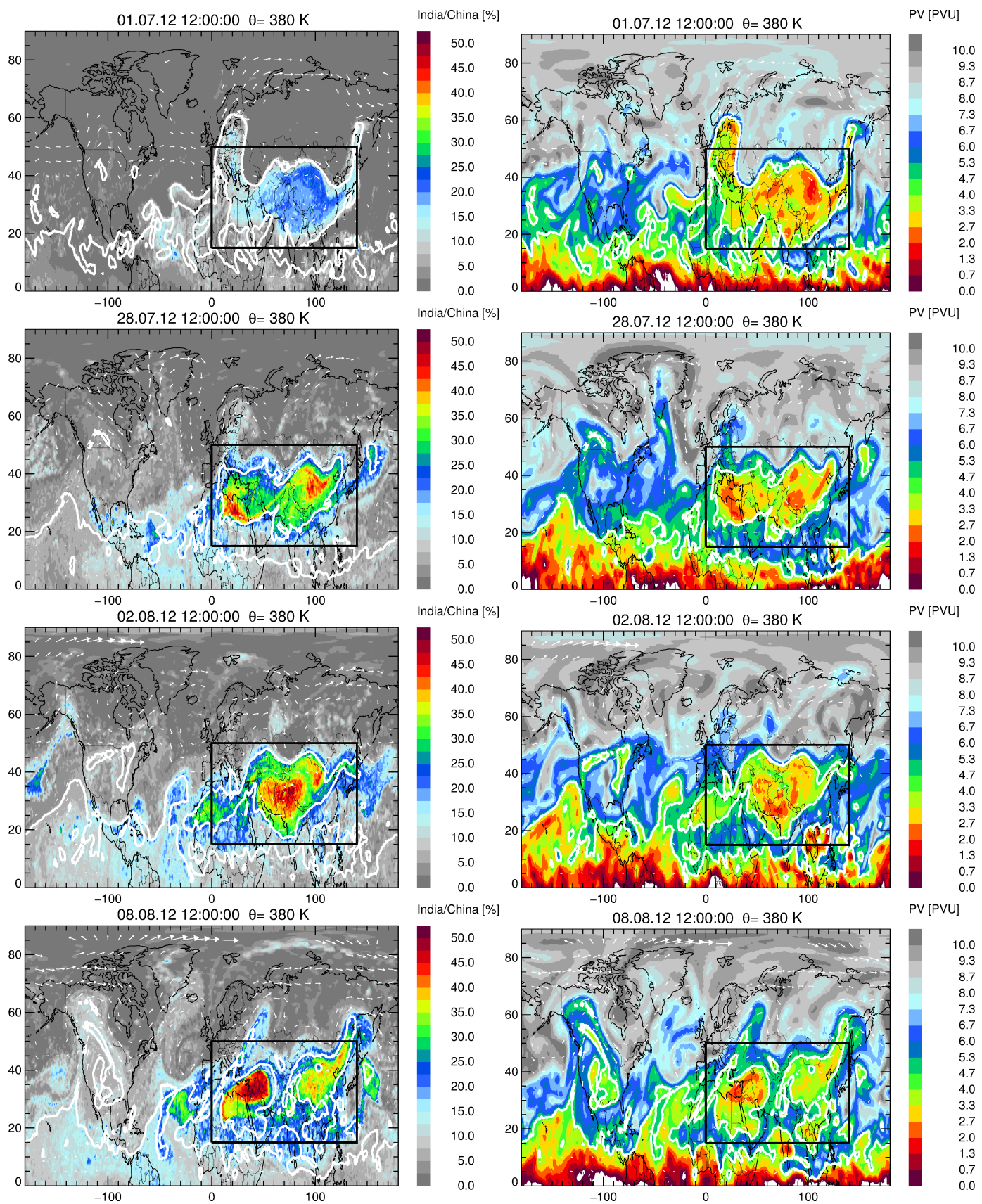

India/China [\%]

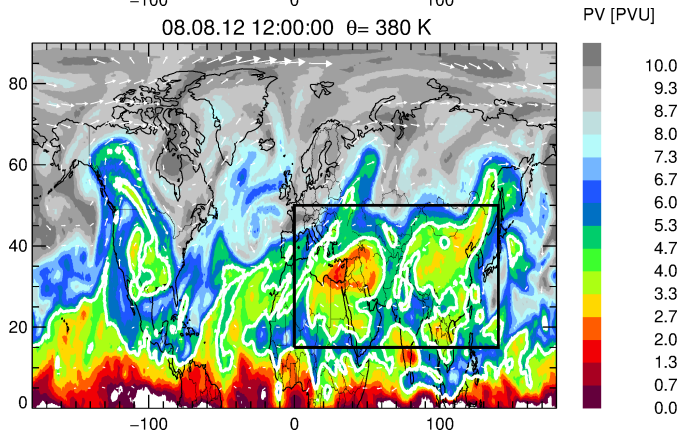

Figure 2. The horizontal distribution of the fraction of air originating in India/China (left) and PV (right) at $380 \mathrm{~K}$ potential temperature over Asia on 1 July 2012 (top), 28 July 2012 (second row), 2 August 2012 (third row), and 8 August 2012 (bottom). Please note that the order of the colour scale for India/China (left) and PV (right) is different, so that high contributions of emission tracers for India/China and low PV are marked in red. The horizontal winds are indicated by white arrows. The black rectangle $\left(15-50^{\circ} \mathrm{N}, 0-140^{\circ} \mathrm{E}\right)$ highlights the region of the Asian monsoon anticyclone. The 4.5 PVU surface marks roughly the edge of the anticyclone shown as a thick white line.

\subsubsection{Comparison with MLS measurements}

To compare our simulation with MLS $\mathrm{O}_{3}$ and $\mathrm{CO}$ measurements (Version 3.3) (Livesey et al., 2008), pattern correlation coefficients between MLS measurements and CLaMS results, namely
$\operatorname{MLS}(\mathrm{CO}) / \mathrm{CLaMS}(\mathrm{CO}), \quad \operatorname{MLS}\left(\mathrm{O}_{3}\right) / \operatorname{CLaMS}\left(\mathrm{O}_{3}\right), \quad$ and MLS(CO) / CLaMS(India/China), were calculated between 360 and $400 \mathrm{~K}$ potential temperature (see Fig. 4). It is expected from satellite measurements that $\mathrm{CO}$ mixing ratios are higher within the Asian monsoon anticyclone than outside and vice versa for $\mathrm{O}_{3}$, indicating that air masses inside 

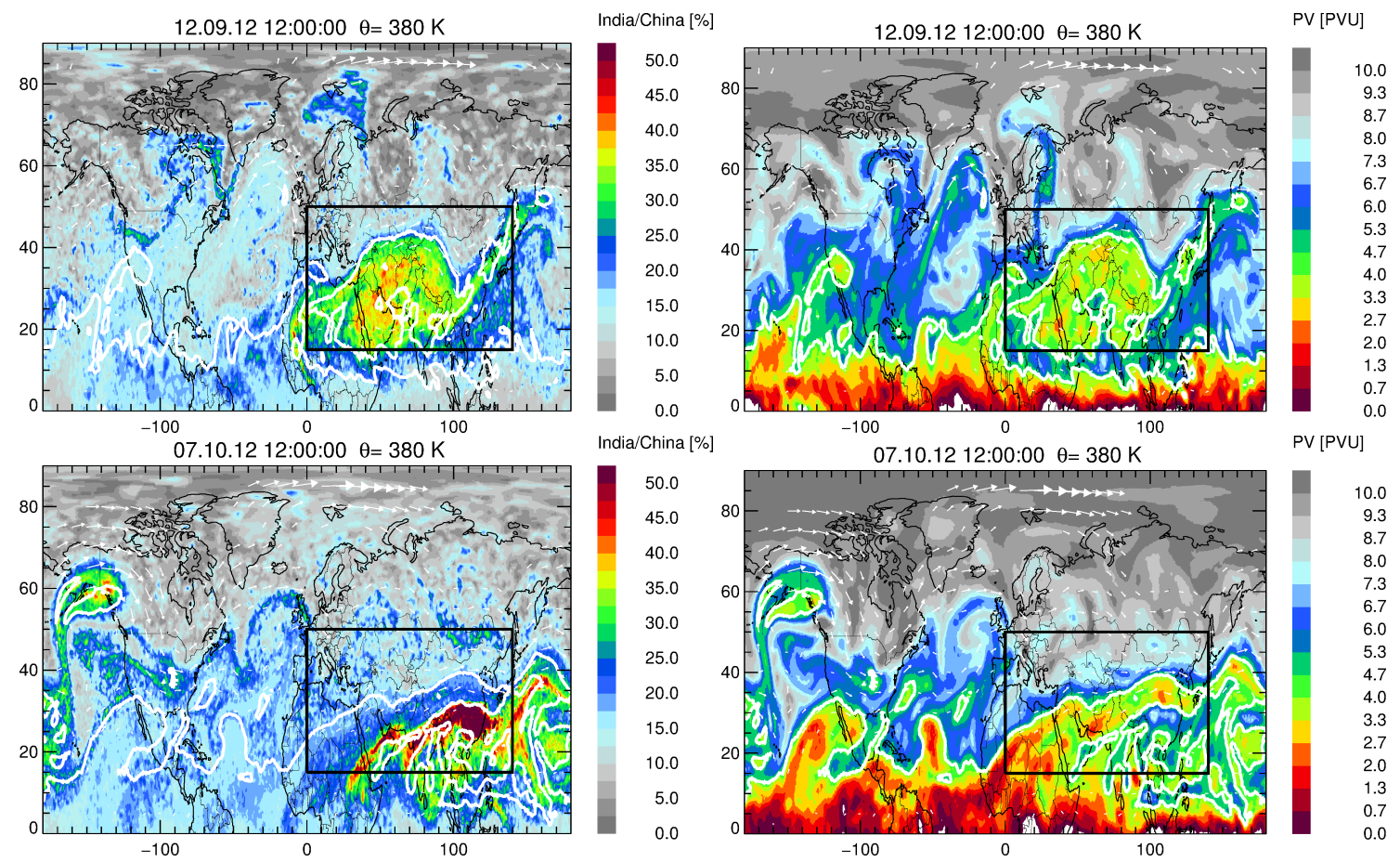

India/China $[\%]$

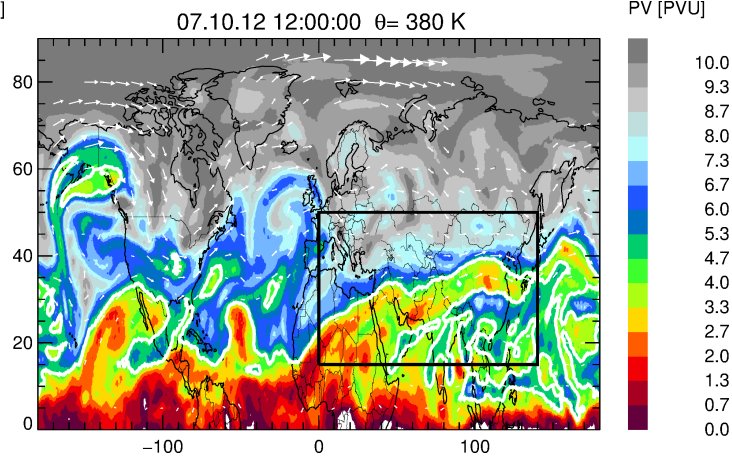

Figure 3. The same as Fig. 2 but on 12 September 2012 (top) during the late phase of the anticyclone and on 7 October 2012 (bottom) showing the distribution of emission tracers for India/China after the breakup of the anticyclone.

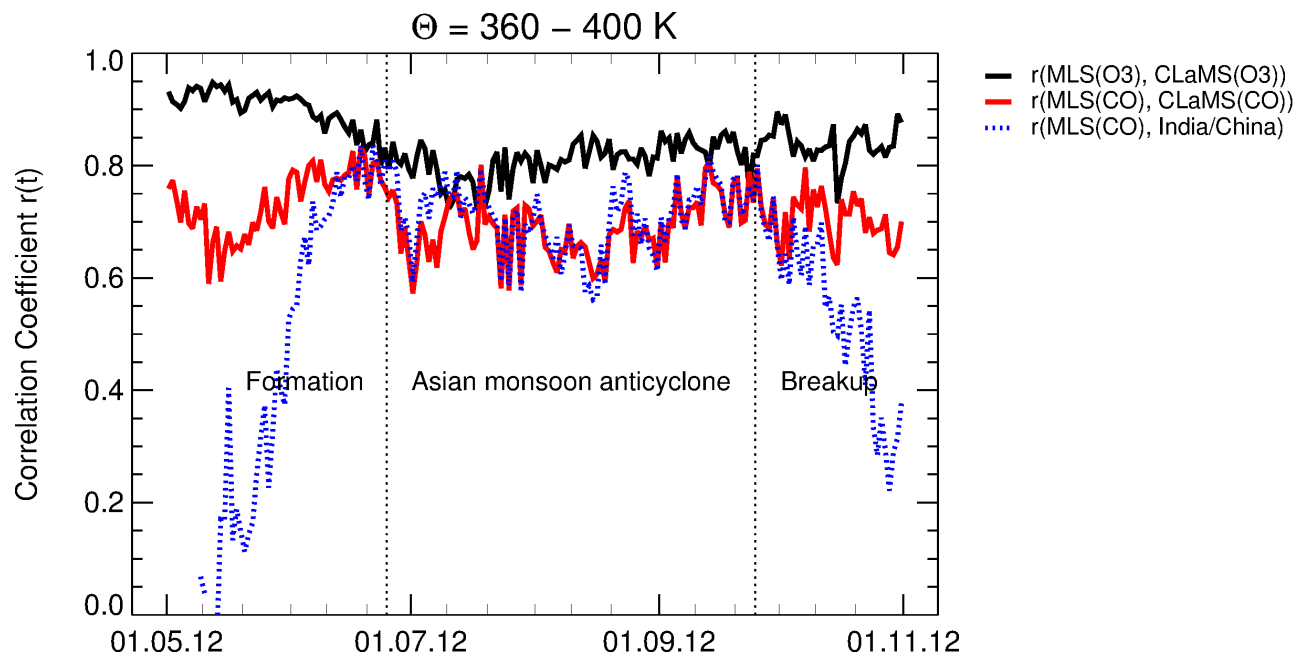

Figure 4. Correlation coefficients depending on time for tracer correlations patterns between $\mathrm{MLS} \mathrm{O}_{3}$ and CLaMS $\mathrm{O}_{3}$ (black), between MLS CO and CLaMS CO (red), and between MLS CO and the CLaMS emission tracer for India/China (blue) for levels of potential temperature between 360 and $400 \mathrm{~K}$ (see text for more details) in a region between 15 and $50^{\circ} \mathrm{N}$ and 0 and $140^{\circ} \mathrm{E}$ (shown as black rectangles in Fig. 2 and 3).

the anticyclone have a stronger tropospheric characteristic than air masses in the UTLS outside of the anticyclone. On all days between 1 May 2012 and 31 October 2012, MLS measurements of $\mathrm{O}_{3}$ and $\mathrm{CO}$ in a region between 15 and $50^{\circ} \mathrm{N}$ and 0 and $140^{\circ} \mathrm{E}$ (shown as black rectangles in Fig. 2) between 360 and $400 \mathrm{~K}$ potential temperature are correlated to CLaMS results as described in the following.
On each day, CLaMS results are interpolated on locations of the MLS measurements transformed to synoptic 12:00 UTC positions. For each day, both MLS measurements and CLaMS results are normalized so that the maximum value of each trace gas is equal to one. Afterwards the linear Pearson correlation coefficient $r(t)$ between MLS measurement and CLaMS results is calculated for each day. This procedure 
allows the spatial distribution of trace gases to be compared neglecting possible differences in the absolute mixing ratios between model and measurement and to compare the spatial distribution of different quantities such as measured $\mathrm{CO}$ and simulated emission tracers (here India/China).

Correlation coefficients $r(t)$ ranging between 0.72 and 0.86 were calculated for $\operatorname{MLS}\left(\mathrm{O}_{3}\right) / \operatorname{CLaMS}\left(\mathrm{O}_{3}\right)$ during the 2012 monsoon season between end of June and end of September. Before the monsoon season in early May, an even higher correlation coefficient up to 0.95 was found for $\operatorname{MLS}\left(\mathrm{O}_{3}\right) / \mathrm{CLaMS}\left(\mathrm{O}_{3}\right)$, most likely caused by the fact that the initial $\mathrm{O}_{3}$ fields in CLaMS for 1 May 2012 are derived from MLS data (see Sect. 2.1).

Correlation coefficients of 0.57 to 0.81 were calculated for both MLS(CO)/CLaMS(CO) and MLS(CO)/CLaMS(India/China) between the end of June and the end of September. These high correlation coefficients confirm that CLaMS has the capability of simulating the spatial distribution of tropospheric trace gases such as $\mathrm{CO}$ and stratospheric trace gases like $\mathrm{O}_{3}$ measured by MLS. In the region of the Asian monsoon anticyclone, the correlation coefficients of $\operatorname{MLS}\left(\mathrm{O}_{3}\right) / \mathrm{CLaMS}\left(\mathrm{O}_{3}\right)$ are somewhat higher than those of MLS(CO)/CLaMS(CO). Reasons for this observation could be deficiencies in MLS CO data (v3) in the lower stratosphere as found by Schwartz et al. (2015), who detect a lack of expected signatures in MLS (v3) CO in the context of double tropopauses, e.g. on the poleward edge of the Asian monsoon anticyclone, and suggest that these deficiencies could be related to unexpectedly weak equator-to-pole gradients of MLS CO in the lower stratosphere (Hegglin and Tegtmeier, 2016). Differences between $\operatorname{MLS}(\mathrm{CO}) / \mathrm{CLaMS}(\mathrm{CO})$ and $\operatorname{MLS}\left(\mathrm{O}_{3}\right) / \mathrm{CLaMS}\left(\mathrm{O}_{3}\right)$ correlations could also be caused by limitations in the convective transport of CO in ERA-Interim reanalysis data (see discussion in Sect.4) or by lower boundary conditions for $\mathrm{CO}$ (see Sect. 2.1). To illustrate the good agreement between CLaMS and MLS, the same horizontal cross-sections as in Figs. 2 and 3 at $380 \mathrm{~K}$ potential temperature for MLS CO and $\mathrm{O}_{3}$ as well as for CLaMS $\mathrm{CO}$ and $\mathrm{O}_{3}$ are shown in the Supplement of this paper.

The correlation coefficient of MLS(CO)/CLaMS(India/China) increases from 0 to $\approx$ 0.8 during the formation of the Asian monsoon anticyclone, as expected because the tracer in the model has first to be transported from the ground to the UTLS. After the breakup of the monsoon anticyclone the correlation coefficient of MLS(CO)/CLaMS(India/China) decreases because further upward transport of the tracer for India/China does not occur due the missing convection in this region and therefore the spatial CO distribution in the UTLS is dominated by other processes. During the existence of the Asian monsoon anticyclone, correlation coefficients of MLS(CO) / CLaMS(India/China) between 0.57 and 0.81 are calculated, indicating that the spatial distribution of $\operatorname{MLS}(\mathrm{CO})$ within the Asian monsoon anticyclone is good, as represented by the spatial distribution of the emission tracers for India/China. This model tracer is therefore a good proxy for the spatial distribution of tropospheric trace gases measured in the Asian monsoon anticyclone.

\subsubsection{Different phases of the Asian monsoon anticyclone}

To link the temporal variation of the spatial distribution of the emission tracers to areas of low PV during the entire Asian monsoon period 2012, pattern correlations between $\mathrm{PV}$ and the emission tracer for Indian/China (red), the emission tracer Southeast Asia (grey), and CLaMS CO (blue) are calculated as shown in Fig. 5. The correlation coefficients are calculated in a region between 15 and $50^{\circ} \mathrm{N}$ and 0 and $140^{\circ} \mathrm{E}$ (shown as black rectangles in Fig. 2) at $380 \mathrm{~K}$ similar to the MLS/CLaMS correlations described above. For each day, CLaMS results and PV are interpolated on a $1 \times 1$ latitude-longitude grid at $380 \mathrm{~K}$ and thereafter normalized to 1.

Figure 5 shows that the spatial distribution of PV and CLaMS CO is strongly anticorrelated during the formation $(-0.89$ to -0.95$)$, the existence $(-0.74$ to -0.93$)$, and the breakup ( -0.68 to -0.89 ) of the Asian monsoon anticyclone. In the course of the Asian monsoon season, a strong anticorrelation between the spatial distribution of low PV and high percentages of the emission tracer for India/China of -0.71 to -0.87 is found. During the formation of the anticyclone, the correlation coefficients decrease because the emission tracer has to be transported up to the UTLS. The increase of the correlation coefficients after the breakup is caused by the lack of convection in Asia during the monsoon season (see comparison between MLS and CLaMS in Sect. 3.1). In contrast, the correlation coefficient between the spatial distribution of PV and the emission tracer for Southeast Asia shows completely different behaviour. During the formation of the Asian monsoon, the contributions of the emission tracer for Southeast Asia decrease similarly as for the emission tracer for India/China. During the existence of the anticyclone a strong anticorrelation with a correlation coefficient up to -0.90 is calculated at the early and late phase of the anticyclone; however, in early August (mid-phase), the spatial distributions of PV and the emission tracer for Southeast Asia are uncorrelated (indicated by the black dashed line in Fig. 5). This shows that in the mid-phase of the Asian monsoon anticyclone, the spatial distribution of air masses originating in Southeast Asia is not connected to the region of the Asian monsoon anticyclone, indicating that air masses from Southeast Asia experienced upward transport outside of the Asian monsoon anticyclone (see Sect. 3.2).

In the course of the Asian monsoon season, the strong correlation and anticorrelation found between the emission tracer for India/China and MLS CO measurements with correlation coefficients between 0.57 and 0.81 as well as PV with correlations coefficients between -0.71 and -0.87 in- 


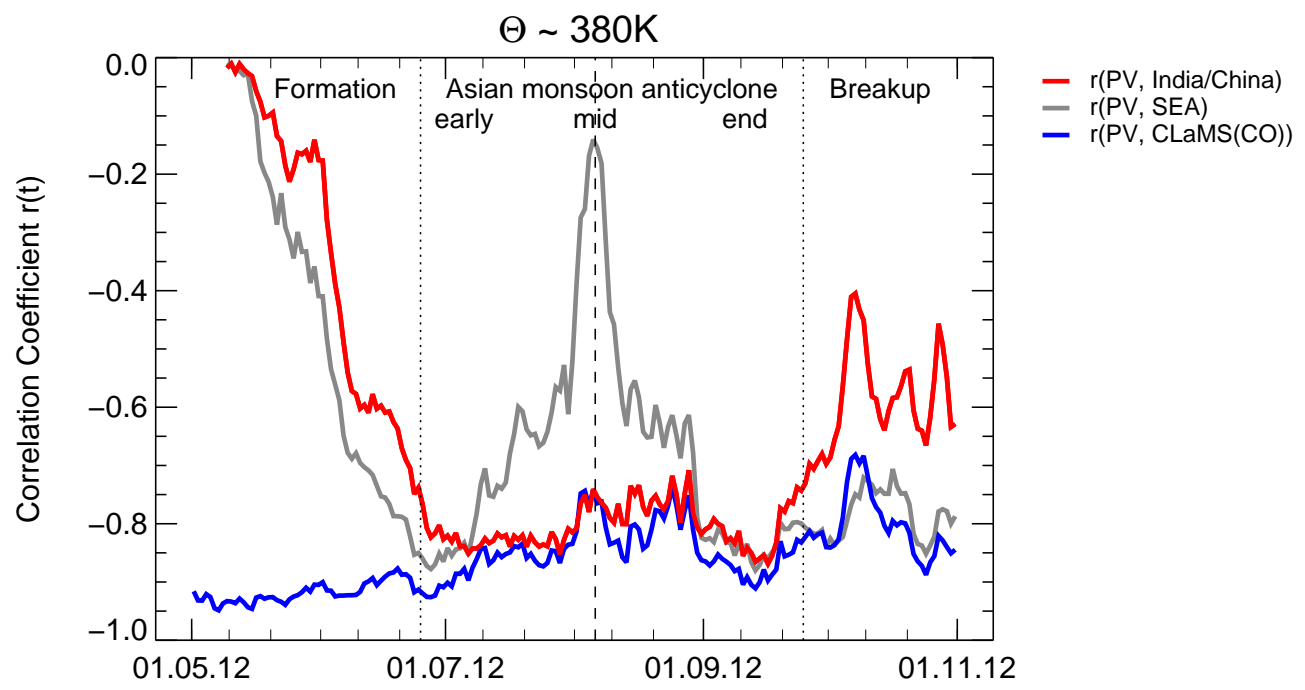

Figure 5. Time-dependent correlation coefficients for the spatial distribution between PV and the emission tracer for India/China (red), the emission tracer for Southeast Asia (grey), and CLaMS CO (blue) at $380 \mathrm{~K}$ potential temperature (see text for more details) in a region between 15 and $50^{\circ} \mathrm{N}$ and 0 and $140^{\circ} \mathrm{E}$ (shown as black rectangles in Figs. 2 and 3).

dicate that the spatial distribution of the emission tracer for India/China is a good proxy for the location and shape of Asian monsoon anticyclone from the end of June to the end of September.

Figure 6 shows 12-day mean values of the emission tracer for India/China and PV during different phases of the Asian monsoon anticyclone. A slight geographical northward shift of the spatial distribution of the emission tracer for In$\mathrm{dia} /$ China is found from the early phase of the anticyclone from the end of June/early July to early August (mid-phase). Further, in early September, the late phase of the anticyclone, a much broader spatial distribution of the emission tracer for India/China is found; in particular the southern edge of the anticyclone is shifted towards the tropics. In early October after the breakup of the anticyclone, high percentages of the emission tracer for India/China are still found over India, China, and the Pacific Ocean.

Animations showing the temporal evolution (on a daily basis) of the contribution of emission tracers for India/China, Southeast Asia, and $\mathrm{PV}$ at $380 \mathrm{~K}$ potential temperature in the Northern Hemisphere during the Asian 2012 monsoon season (1 May 2012-late October 2012) are available as a Supplement of this paper, showing the intraseasonal variability of the Asian monsoon anticyclone. In the next sections, the spatial distribution of different emission tracers for Asia within the Asian monsoon anticyclone and the temporal evolution of all tracers within the Asian monsoon anticyclone from May until late October 2012 are discussed.

\subsection{Impact of different emission tracers on the composition of the Asian monsoon anticyclone}

To analyse the possible impact of different boundary layer source regions in Asia, in particular the specific importance of Southeast Asia, on the composition of the Asian monsoon anticyclone, the horizontal distributions of emission tracers are discussed at $380 \mathrm{~K}$ potential temperature using 4 days introduced in the previous section (1 July, 2 and 8 August, and 12 September 2012; see Sect. 3.1). The emission tracers for northern India, southern India, and eastern China show in general the same horizontal patterns; therefore here we show only emissions from northern India. However, their individual contributions to the composition of the anticyclone differ from tracer to tracer and are time dependent (see Sect. 3.2.1). In the previous section (Sect. 3.1), it was shown that the spatial distribution of the emission tracer for Southeast Asia has fundamentally different behaviour than the distribution for emission tracers for northern India, southern India, and eastern China at $380 \mathrm{~K}$ potential temperature (see Fig. 5).

Figure 7 shows the horizontal distribution of emission tracers for northern India (left) and Southeast Asia (right) at $380 \mathrm{~K}$ potential temperature over Asia for the 4 chosen days. In the early phase on 1 July 2012 (Fig. 7, top), air masses from boundary layer sources in northern India and Southeast Asia are confined within the Asian monsoon anticyclone and within the filaments at its western and eastern flank. Air masses influenced by boundary layer sources from Southeast Asia are also found in the tropics. Within the anticyclone, the emission tracer for Southeast Asia has the largest contribution at $380 \mathrm{~K}$, followed by the emission tracers for northern India. 

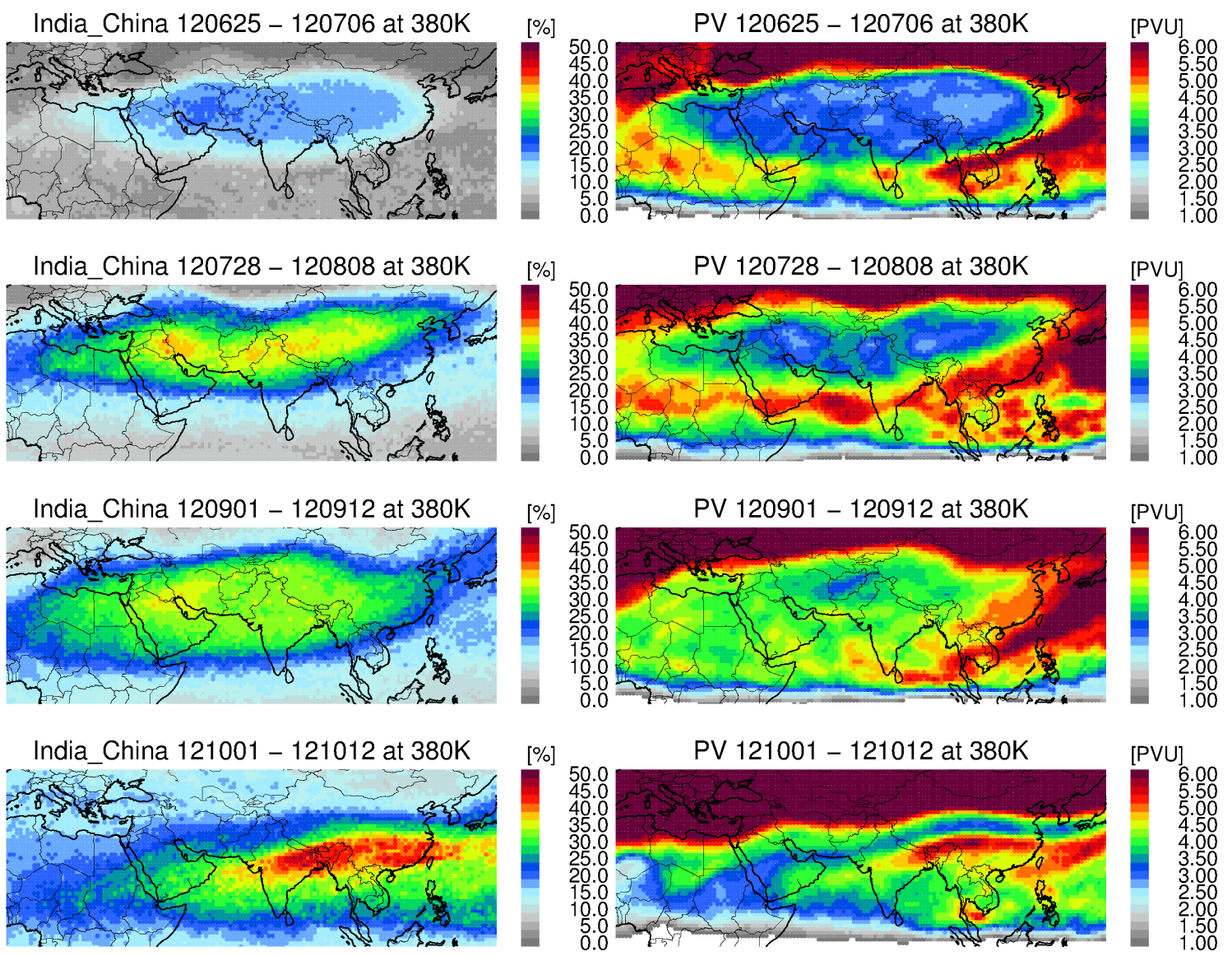

Figure 6. Twelve-day mean values of the contribution of the emission tracer for India/China (left) and PV (right) during four different phases of the Asian monsoon anticyclone: early phase (top), mid-phase (second row), end phase (third row) of the anticyclone, and after the breakup (bottom).

Similar to the distribution on 1 July 2012, the distribution of the emission tracer for northern India on 2 August 2012 in the mid-phase at $380 \mathrm{~K}$ (Fig. 7, second row, left) is also confined within the Asian monsoon anticyclone.

In contrast to 1 July, the highest percentages of emission tracers within the anticyclone at the beginning of August are from northern India and eastern China (not shown here); thus the impact of boundary sources located more northwards is larger than the impact of boundary sources from Southeast Asia and southern India (not shown here).

Further, on 2 August 2012 at $380 \mathrm{~K}$, the spatial distribution of the emission tracers for northern India shows two regions with maximum values: one in the core of the anticyclone over Iran and Afghanistan and another within the anticyclone farther northeast over China which is a remnant of a double peak structure found on 28 July 2012 as discussed previously in Sect. 3.1.

On 2 August 2012, the horizontal distribution of the emission tracer for Southeast Asia is completely different compared to the 1 July 2012. On 2 August 2012 (Fig. 7, second row, right), the contribution of the emission tracer for South- east Asia has a local minimum in the core of the anticyclone surrounded by enhanced percentages of the emission tracer for Southeast Asia at the edge of the anticyclone particularly at the southeast edge of the anticyclone and in the western and eastern filaments of the anticyclone. This is in contrast to the emission tracers for northern India (and eastern China, not shown here) which have large contributions in the core and low values at the edge. Therefore, the spatial distribution of the emission tracer for Southeast Asia within the anticyclone is like a negative image of the spatial distribution of the emission tracer for northern India. Looking at a wider geographical scale, large contributions of the emission tracer for Southeast Asia are found south of the anticyclone in the tropics, over the Pacific Ocean, and west of the anticyclone over the South Atlantic Ocean.

On 8 August 2012 (Fig. 7, third row), the Asian monsoon anticyclone is split into two smaller anticyclones. Apart from the double peak structure, the spatial distribution of the emission tracer for northern India and Southeast Asia is similar to the distribution on 2 August 2012, i.e. high contributions from northern India and low contributions from Southeast 

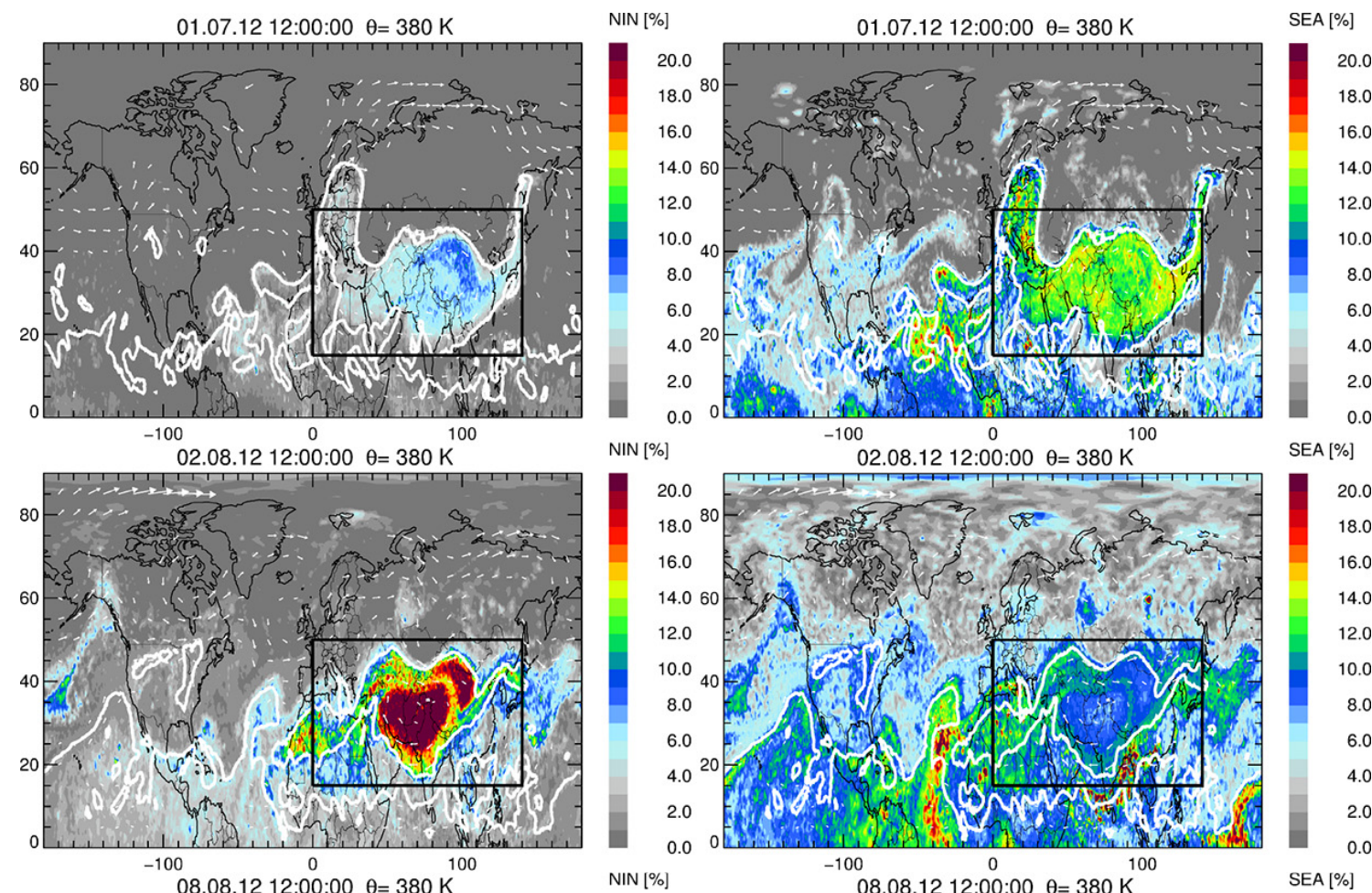

SEA [\%]
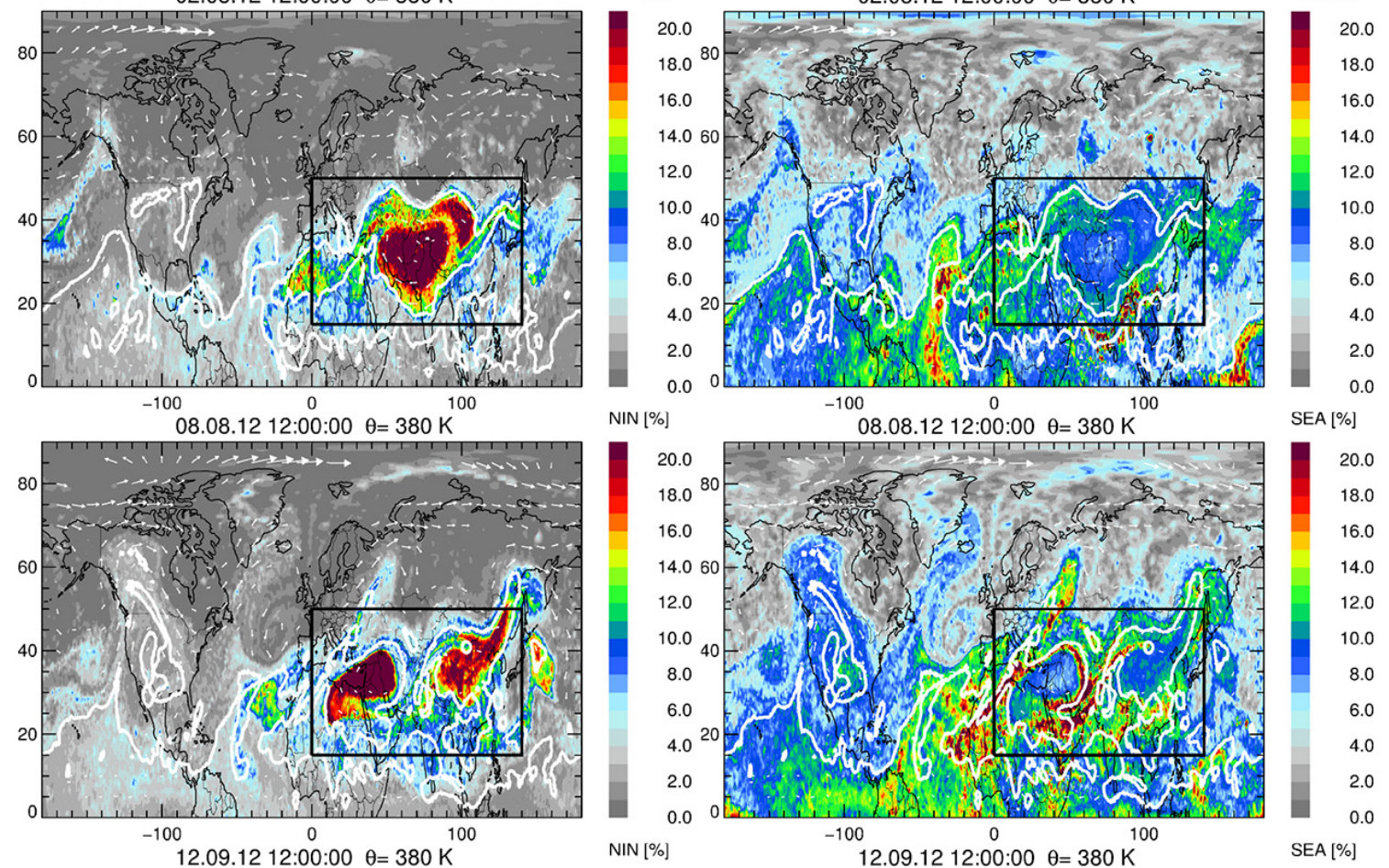

SEA [\%]
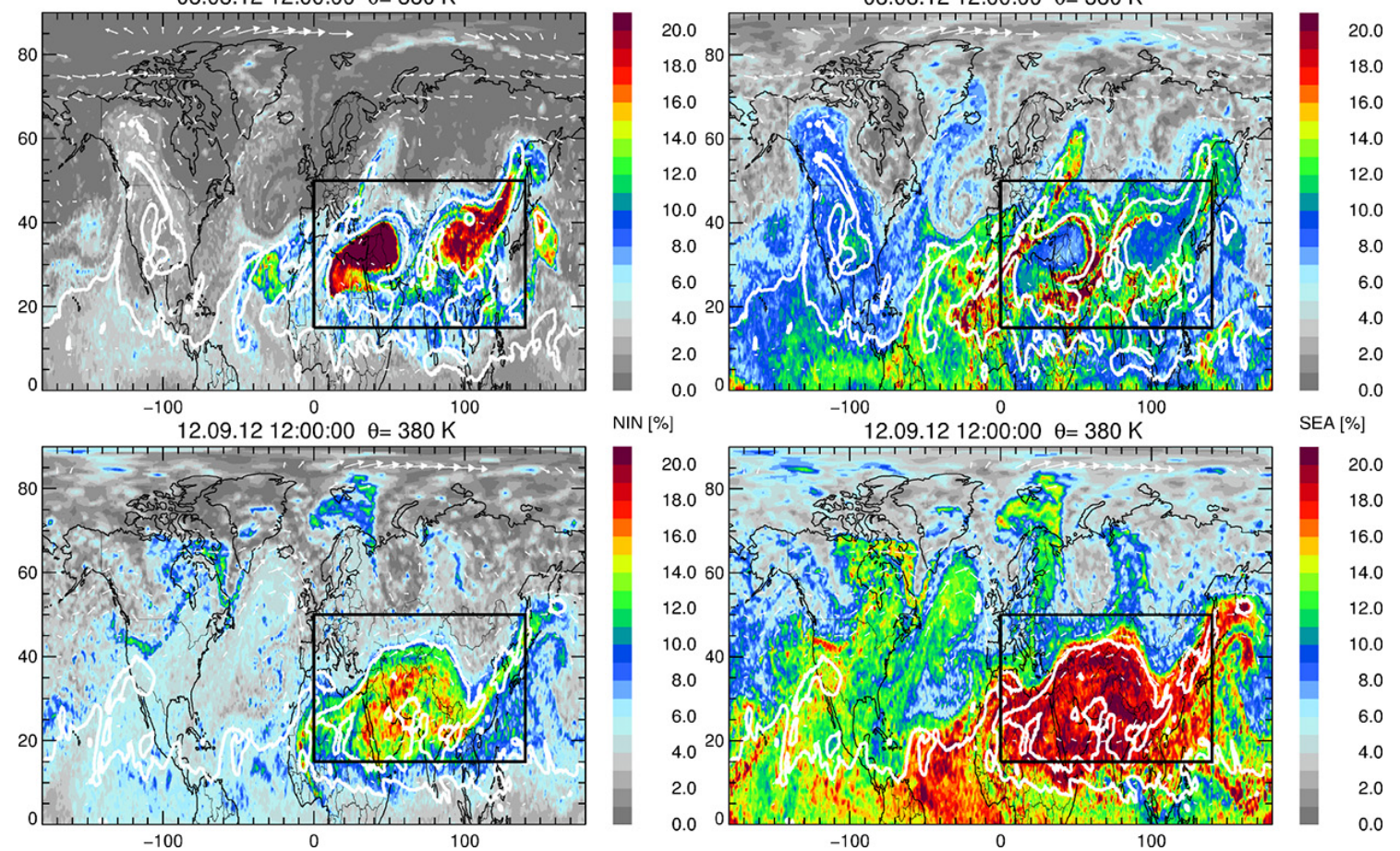

Figure 7. The horizontal distribution of the fraction of air originating in (left) northern India (NIN) and (right) Southeast Asia (SEA) at $380 \mathrm{~K}$ potential temperature over Asia on 1 July 2012 (top), 2 August 2012 (second row), 8 August 2012 (third row), and 12 September 2012 (bottom). The horizontal winds are indicated by white arrows. The black rectangle $\left(15-50^{\circ} \mathrm{N}, 0-140^{\circ} \mathrm{E}\right)$ highlights the region of the Asian monsoon anticyclone. The 4.5 PVU surface marks roughly the edge of the anticyclone shown as a thick white line.

Asia are found within both cores of the anticyclones. Also here, remarkably high percentages of the emission tracer for Southeast Asia appear at the edge of the two anticyclones.
Thus at the beginning of August 2012, the percentage of emission tracers for northern India and eastern China (not shown here) outweigh the percentage of the emission tracers 
from further south for Southeast Asia and southern India (not shown) inside the anticyclone in contrast to the conditions in the early phase on 1 July.

Air masses originating in Southeast Asia can experience strong uplift by deep convection (e.g. Park et al., 2007; Li et al., 2005) or typhoons (Vogel et al., 2014). If an air parcel is uplifted at the edge of the Asian monsoon to altitudes high enough, it can be entrained into the anticyclonic circulation and subsequent clockwise transport of the air parcels around the outer edge of the anticyclone occurs. The edge of the anticyclone acts here as a strong transport barrier, as evident in the strong gradients of the different emission tracers at the edge of the anticyclone. The transport barrier acts in both directions, namely for inward transport apparent in the tracer distribution from Southeast Asia and for outward transport apparent in the tracer distribution for northern India (see Fig. 7, second and third row). Further, air masses originating in the boundary layer in Southeast Asia are uplifted in the tropics at locations where they do not reach the Asian monsoon anticyclone. A subsequent isentropic poleward transport of these air masses from the tropics to the region of the Asian monsoon anticyclone is evident in the CLaMS simulation.

On 12 September 2012 (see Fig. 7, bottom) during the late phase, the anticyclone is broadened to the south compared to the area of the Asian monsoon anticyclone in July and August. In the core of the Asian monsoon anticyclone, the main contributions are emission tracers for Southeast Asia and northern India followed by eastern China (not shown). A smaller percentage is found for the emission tracer for southern India (not shown).

Further, on 12 September 2012 at the end of the monsoon season, the spatial distribution of the emission tracer for Southeast Asia at $380 \mathrm{~K}$ is very different compared to the distributions of the emission tracer for northern India particularly within the Northern Hemisphere. During the late phase of the anticyclone, contributions of the emission tracers for northern India are still trapped within the anticyclone. As discussed before, air masses originating in the boundary layer in Southeast Asia are uplifted both within the Asian monsoon anticyclone and elsewhere in the tropics. Uplift in the tropics and subsequent isentropic poleward transport at around $380 \mathrm{~K}$ yield propagation of air masses originating in the boundary layer of Southeast Asia to mid-latitudes. Fig. 7 (bottom) shows that on 12 September 2012, contributions from Southeast Asia between 6 and $10 \%$ are found in the entire Northern Hemisphere. Therefore, the extratropical lowermost stratosphere in the Northern Hemisphere is flooded by the end of September with air masses from Southeast Asia. As a result, high percentages of the emission tracer for Southeast Asia are more widely distributed compared to the distribution of the emission tracers for northern India, southern India, and eastern China.

\subsubsection{Temporal evolution of different emission tracers}

The artificial emission tracers in CLaMS are designed to identify possible boundary source regions in Asia that could contribute to the composition of the Asian monsoon anticyclone during the 2012 monsoon season (as defined in Sect. 2.1.1) considering advection and mixing processes. By this technique, contributions of the boundary layer with a transport time from the boundary to the UTLS in the range of one monsoon period (contributions from the boundary layer that are released after 1 May 2012) are covered by the artificial tracers used here. Therefore, the composition of different emission tracers within the Asian monsoon anticyclone is a fingerprint of the regional and temporal variations of convective processes causing strong upward transport within the Asian monsoon anticyclone in summer 2012.

After presenting the spatial distribution of the emission tracers in Sect. 3.2 for 4 selected days, we will now discuss the temporal evolution of all emission tracers within the Asian monsoon anticyclone in 2012. In the previous sections, it was shown that the area enclosed by the 4.5 PVU isoline constitutes a good upper boundary for the area within the Asian monsoon anticyclone at $380 \mathrm{~K}$ showing enhanced contributions of emission tracers for India/China within the Asian monsoon anticyclone. Ploeger et al. (2015) inferred a mean value of 3.8 PVU to mark the transport barrier for the Asian monsoon anticyclone 2012 at $380 \mathrm{~K}$ using the PV gradient and horizontal circulation. However, the PV value marking the transport barrier changes from day to day with maximum PV values up to 4.4-4.6 PVU and could only be deduced for a period from 20 June to 20 August 2012 (Ploeger et al., 2015). In our study, a value of 4.5 PVU is used which is in agreement with the upper limit of the PV values derived by Ploeger et al. (2015) and is extrapolated to early June and September/October 2012.

Therefore, to calculate the percentage of different emission tracers within the Asian monsoon anticyclone at $380 \mathrm{~K}$ we use the following assumption: mean values of all emission tracers are calculated in Asia for the region between 15 and $50^{\circ} \mathrm{N}$ and 0 and $140^{\circ} \mathrm{E}$ (at $380 \pm 0.5 \mathrm{~K}$; shown as black rectangles in Fig. 7). In addition to this geographical limit (black rectangles), PV values lower than 4.5 PVU are required for an air parcel to contribute to the mean values of the different emission tracers within the Asian monsoon anticyclone for each day, as shown in Fig. 8.

The contribution of different emission tracers from Asia within the anticyclone differ in time and from tracer to tracer (Fig. 8). The temporal evolution shows that significant contributions of the emission tracer for Southeast Asia (black) are found within the Asian monsoon anticyclone at $380 \mathrm{~K}$ potential temperature at the end of May, which is roughly 2 weeks before contributions of the emission tracers for northern India (red), southern India (blue), and eastern China (green) reach that level of potential temperature. At the beginning of the Asian monsoon period in June/early July, contributions 


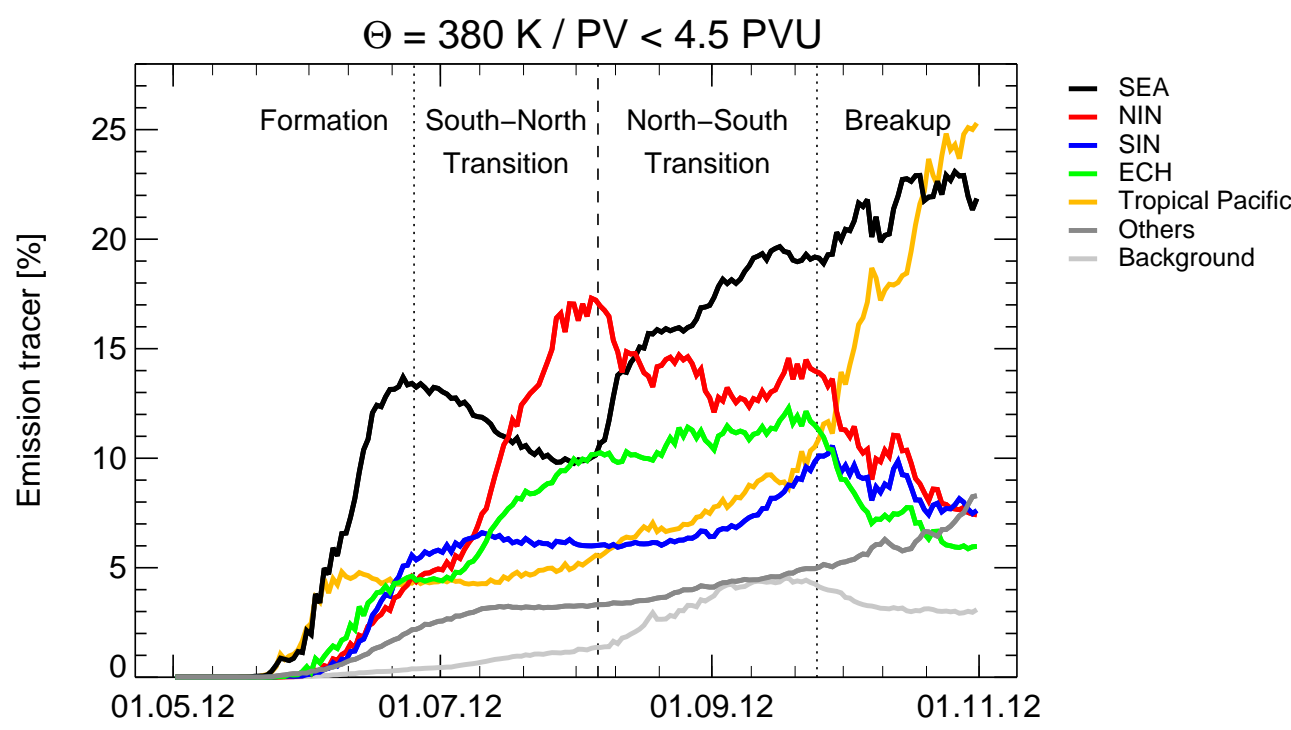

Figure 8. Temporal evolution of different emissions tracers from Southeast Asia (SEA, black), northern India (NIN, red), southern India (SIN, blue), eastern China (ECH, green), tropical Pacific Ocean (yellow), and from all other land masses plus tropical Atlantic/Indian Ocean (others, dark grey) within the Asian monsoon anticyclone at $380 \mathrm{~K}$ from May 2012 until the end of October 2012. Contributions of boundary sources not considered in the defined emissions tracers listed in Table 1 are summarized as background (light grey). The shown percentages are mean values calculated for air masses in Asia in the region between 15 and $50^{\circ} \mathrm{N}$ and 0 and $140^{\circ} \mathrm{E}$ at $380 \pm 0.5 \mathrm{~K}$ (see black rectangles in Fig. 7) with PV values lower than 4.5 PVU, marking the edge of the anticyclone.

of air masses originating in South Asia dominate within the anticyclone with maximum percentages of emission tracers on average of $13 \%$ for Southeast Asia (black) and $6.5 \%$ for southern India (blue) at $380 \mathrm{~K}$. During July 2012, the contributions of emission tracers for the south decrease to $10 \%$ (Southeast Asia) and 6\% (southern India) while contributions of emission tracers for the north, northern India (red) and eastern China (green) increase up to 18 and $10 \%$, respectively, until early August. During August 2012, the percentage of the emission tracers for the south rises again until the breakup of the anticyclone, which occurred at the end of September, in contrast to decreasing contributions of emission tracers for northern India. Our simulations show that a south-north shift in the contribution of different emission tracers for Asia within the Asian monsoon anticyclone occurs during summer 2012 and also a slight northward shift of the anticyclone itself. This behaviour is possibly linked to the northward moving long-term interseasonal variations (30to-60-day oscillations) found in climatological analyses of monsoon activity like convection and rainfall (e.g. Goswami, 2012, and references therein).

During August and September 2012, contributions of the emission tracer for northern India (red) decrease in general; however, short-term intraseasonal variations (10-20 days) as a local phenomenon are found. We suggest that these oscillations are most likely connected to the short-term westwardpropagating intraseasonal variations (10-20 days) of the Asian summer monsoon found on a smaller horizontal scale (e.g. Goswami, 2012, and references therein). In the same time period, contributions of the emission tracer for eastern China show a slight increase with maximum percentages at the end of September.

At the end of September 2012, the contributions of emission tracers for northern India, southern India, and eastern China start to decrease caused by the breakup of the Asian monsoon anticyclone and the missing upward transport within the anticyclone. In contrast to these tracers, the contribution of emission tracers for Southeast Asia increases continuously up to $23 \%$ from its minimum percentage of $10 \%$ in late August until the end of October. In early October, the anticyclone had already dissolved, but the contributions of the emission tracer for Southeast Asia still rise. The reason for this increase is that air masses originating in the boundary layer in Southeast Asia experienced, in addition to the upward transport in the Asian monsoon anticyclone itself, uplift in the tropics and rapid uplift over the Pacific Ocean. The contribution of the emission tracer for the tropical Pacific Ocean increases after the breakup of the anticyclone (yellow) indicating a strong uplift of air masses in the tropical Pacific. The influence of other land masses together with tropical Atlantic and Indian oceans (dark grey line in Fig. 8) and of the background (light grey) is of minor importance throughout the considered time period.

The conclusions deduced from the temporal evolution of emission tracers do not depend on the precise value of 4.5 PVU. Very similar results were obtained for a choice of 3.8 PVU. Further, even if no PV criterion is applied and all air parcels within the geographical limits (black rectangles in 


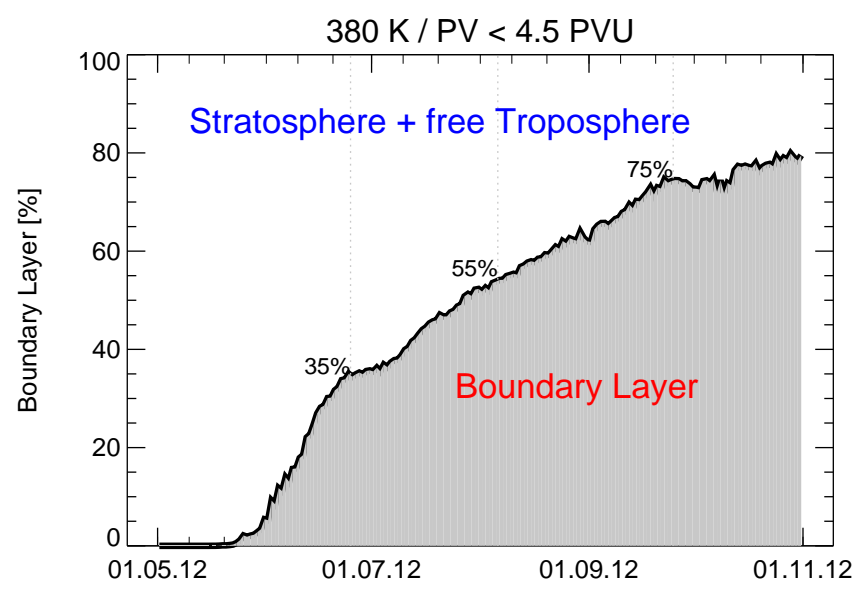

Figure 9. Temporal evolution of contributions of air masses from the boundary layer to the composition of the Asian monsoon anticyclone. The shown percentages are mean values calculated for air masses in Asia in the region between 15 and $50^{\circ} \mathrm{N}$ and 0 and $140^{\circ} \mathrm{E}$ at $380 \pm 0.5 \mathrm{~K}$ (see black rectangles in Fig. 7) with PV values lower than 4.5 PVU marking the edge of the anticyclone.

Figs. 2, 3, and 7) are considered when calculating the mean values, the same qualitative evolution of the contributions of different emission tracers emerges within the anticyclone at $380 \mathrm{~K}$. However, when using only the geographical limits the highest contributions from Southeast Asia up to 11 and $19 \%$ are calculated in mid-June/mid-July and October respectively. The contribution of air masses from northern India has also its maximum in the intervening period from mid-July to mid-August and reaches values up to $13 \%$ (not shown here).

The sum of all emission tracers shown in Fig. 8 is less than $100 \%$ because air masses originating in the free troposphere or stratosphere also contribute to the composition of Asian monsoon anticyclone. For the end of June, a contribution of $35 \%$ of the model boundary layer to the composition of the Asian monsoon anticyclone is calculated as shown in Fig. 9. The remaining $65 \%$ of the composition of the anticyclone is from the free troposphere and the stratosphere. The contribution of the model boundary layer rises up to $55 \%$ in early August and up to $75 \%$ at the end of the monsoon season in late September. Thus at the end of the 2012 monsoon season, the chemical composition of the Asian monsoon anticyclone is dominated by contributions of the model boundary layer uplifted during the course of the 2012 monsoon season since 1 May 2012.

\section{Discussion}

In this paper, we want to show how the impact of different emission tracers changed during the course of the 2012 Asian monsoon season with a focus on the influence of fresh emissions from different regions. Therefore, we se- lected 1 May 2012 as the starting point for our simulation, which is before the formation of the Asian monsoon anticyclone. Of course, air masses emitted in the Earth's boundary layer before 1 May 2012 will contribute to the composition of the Asian monsoon anticyclone, but here we aim at quantifying the impact of young air masses in one particular Asian monsoon season that experienced upward transport in the vicinity of the Asian monsoon anticyclone. Our results therefore demonstrate the influence of young air masses on the composition of the Asian monsoon and on the extratropical lowermost stratosphere. Using this approach, we could show that at the end of the monsoon season in September up to $75 \%$ of the air masses within the Asian monsoon anticyclone are younger than 5 months (see Fig. 9). That implies that the impact of air masses older than 5 months has only a moderate impact on the composition of the Asian monsoon anticyclone at the end of the monsoon season. Our results demonstrate that the Asian monsoon system is an effective pathway for the transport of air masses from the Earth's surface into the upper troposphere within a few months during the course of the 2012 Asian monsoon season.

In contrast to our study, Orbe et al. (2015) used tracers of air mass origin in model simulations to infer the impact of boundary regions in Asia to the tropical lower stratosphere with an approach that the different tracers have equilibrated so that the sum of all tracers of air mass origin is equal to unity within the entire atmosphere (using a spin-up of 20 years). This approach provides for each air parcel the information about the origin within the boundary layer. However, this approach provides no information on the transport times from the boundary layer in Asia to the tropical lower stratosphere. To infer the transport times in the approach by Orbe et al. (2015), they introduce a boundary impulse response that marks air that left the boundary layer on a certain day (1 July). They infer transport times of 1 month from the boundary layer in Asia into the tropical lower stratosphere in July when the Asian monsoon is active. In this respect, their pulse serves a similar purpose as our seasonal tracer set-up. However, our approach considers all air masses that left the boundary layer over the course of the 2012 monsoon season since May and thus reflects the meteorological conditions of the entire 2012 monsoon season.

In our approach, the absolute percentages of the emission tracers found within the Asian monsoon anticyclone depend on the starting point of the model simulations on 1 May 2012. However, the temporal behaviour of the individual emission tracers depends on convective processes causing strong upward transport within the Asian monsoon anticyclone in summer 2012 and are therefore a fingerprint of the regional and temporal variations during the course of the monsoon season. This approach gives insights in the temporal variability of the composition of the Asian monsoon anticyclone over the course of the 2012 monsoon period complementing earlier studies which analysed the origin of air masses within the Asian monsoon anticyclone for a certain shorter period 
of the monsoon season (e.g. Li et al., 2005; Bergman et al., 2013) or infer mean values of air mass origin for the entire monsoon season (e.g. Park et al., 2009; Chen et al., 2012; Fadnavis et al., 2014).

The upward transport and convection in CLaMS is driven by ERA-Interim reanalysis data in which changes are implemented to improve deep and mid-level convection compared to previous reanalysis data (Dee et al., 2011). However, small-scale rapid uplift in convective cores is not included. We expect that in data sets additionally including the smallscale rapid uplift in convective cores, the uplift of air masses within the Asian monsoon should be even more pronounced. However, previous studies (e.g. Ploeger et al., 2010; Pommrich et al., 2014; Vogel et al., 2014) show that ERA-Interim reanalysis data are well suited to study transport processes in the vicinity of the Asian monsoon anticyclone and in the tropical tropopause layer. In addition, the diabatic approach with potential temperature is used in CLaMS as the vertical coordinate (Pommrich et al., 2014), which is suggested to yield more reliable results compared to kinematic calculations (e.g. Ploeger et al., 2010; Bergman et al., 2015).

\section{Conclusions}

In this paper, the impact of different boundary layer source regions in Asia on the composition of the 2012 Asian monsoon anticyclone is characterized by CLaMS model simulations using artificial emissions tracers. Our simulations show that the Asian monsoon anticyclone is highly variable in location and shape and the edge of the anticyclone constitutes a strong transport barrier for artificial emission tracers.

The calculated correlation coefficients indicate good agreement between the horizontal distributions of simulated $\mathrm{CO}, \mathrm{O}_{3}$, and artificial emission tracers for India/China with patterns found in satellite measurements of $\mathrm{O}_{3}$ and $\mathrm{CO}$ by Aura-MLS. For the monsoon season, correlation coefficients $r(t)$ of $0.72-0.86$ and $0.57-0.81$ were calculated for $\operatorname{MLS}\left(\mathrm{O}_{3}\right) / \mathrm{CLaMS}\left(\mathrm{O}_{3}\right)$ and both $\operatorname{MLS}(\mathrm{CO}) / \mathrm{CLaMS}(\mathrm{CO})$ and MLS(CO)/CLaMS(India/China) correlations respectively. In addition in the course of the Asian monsoon season, a strong anticorrelation is found between the emission tracer for India/China and PV with correlation coefficients between -0.71 and -0.87 . These correlation coefficients between the emission tracer for India/China and MLS measurements as well as PV indicate that the spatial distribution of the emission tracer for India/China is a good proxy for the location and shape of Asian monsoon anticyclone. A slight geographical northward shift of the spatial distribution of the emission tracer for India/China is found from the early phase of the anticyclone at the end of June/early July to early August (midphase). Further, in early September, during the late phase of the anticyclone, a much broader spatial distribution is found; in particular, the southern edge of the anticyclone is shifted to the tropics. High percentages for the emission tracer for
India/China located over India, China, and the Pacific Ocean are still found after the breakup of the anticyclone in early October.

In this paper, we could answer the question of what is the impact of different boundary layer sources in Asia to the Asian monsoon anticyclone in summer 2012. The model results show that emissions from northern India, southern India, eastern China, and Southeast Asia have a larger impact on the composition of the Asian monsoon anticyclone than emission tracers from all other land masses. The contributions of these different emission tracers on the composition of the anticyclone are highly variable in time, but in general the highest contribution are from northern India and Southeast Asia. In the early (around June to mid-July) and late period (September/October) of the 2012 monsoon season, contributions from Southeast Asia are highest (up to 13 and $23 \%$ respectively using a value of $4.5 \mathrm{PVU}$ to mark the edge of the anticyclone). In the intervening period (around mid-July to mid-August), air masses from northern India have the strongest contribution to the composition of the anticyclone (up to $18 \%$ ). This behaviour is likely caused by the large-scale northward-moving 30-to-60-day oscillations of the Asian monsoon evident in repeatedly northwardpropagating wet spells during the summer monsoon season. Short-term intraseasonal variations (10-20 days) are found in the contribution for air masses originating in northern India, which is likely associated with westward-propagating 10-to-20-day oscillations of the South Asian summer monsoon found on a smaller horizontal scale. Our simulation confirms that both northern India, including the Tibetan Plateau (Bergman et al., 2013), and Southeast Asia, including the eastern part of Bay of Bengal, South Asian subcontinent, Western Pacific, and the Philippine Seas (Park et al., 2009; Chen et al., 2012), are important source regions for the chemical composition of the Asian monsoon anticyclone. Our simulations demonstrate that the contributions of different boundary source regions to the composition of the Asian monsoon anticyclone show strong intraseasonal variations. Thus, the chemical contribution of the Asian monsoon anticyclone is a fingerprint of the regional temporal variation of convective processes. The variability of the composition of the Asian monsoon anticyclone over the course of the monsoon season is therefore more complex than hitherto believed.

In addition, emissions from Southeast Asia are found both within the Asian monsoon anticyclone and at the outer edge of the anticyclone. CLaMS simulations show that emissions from Southeast Asia can be rapidly uplifted by deep convection ( $\mathrm{Li}$ et al., 2005; Chen et al., 2012) or typhoons (Vogel et al., 2014) up to the outer edge of the anticyclone (at around $380 \mathrm{~K}$ ). Afterwards, the emissions are entrained by the anticyclonic circulation of the Asian monsoon and circulate clockwise, in an upward spiral, at the edge of the Asian monsoon anticyclone around its core (this is also true if the anticyclone is split into two smaller anticyclones). Moreover, 
our simulations show that air masses originating in Southeast Asia can be uplifted elsewhere in the deep tropics and subsequently spread out during the simulation globally on the tropical side of the subtropical jet stream at around $380 \mathrm{~K}$. In contrast, emissions from northern India, southern India, and eastern China are trapped in the Asian monsoon anticyclone. During summer 2012, this mechanism caused flooding of the lowermost stratosphere with relatively young air masses originating from Southeast Asia. Finally, after the breakup of the Asian monsoon anticyclone in late September 2012, emissions from northern India, southern India, and eastern China that has been trapped within the Asian monsoon anticyclone are distributed globally within the UTLS.

Our findings demonstrate that emissions from India/China and Southeast Asia carrying moisture and pollution affected by the circulation of the Asian monsoon anticyclone have a significant impact on the chemical compositions of the lowermost stratosphere of the Northern Hemisphere in particular at end of the monsoon season in September/October 2012.

\section{The Supplement related to this article is available online at doi:10.5194/acp-15-13699-2015-supplement.}

Acknowledgements. The authors sincerely thank Paul Konopka, Felix Plöger, and Reinhold Spang (all at Research Centre Jülich) for helpful discussions. We thank the MLS scientific team (Aura Microwave Limb Sounder) for providing satellite data and the European Centre of Medium-Range Weather Forecasts (ECMWF) for providing the ERA-Interim reanalysis data. The authors gratefully acknowledge the computing time granted on the supercomputer JUROPA at Jülich Supercomputing Centre (JSC) under the VSR project ID JICG11. Our activities were partly funded by the German Science Foundation (Deutsche Forschungsgemeinschaft) under the project LASSO (HALO-SPP 1294/GR 3786) and by the European Community's Seventh Framework Programme (FP7/2007-2013) under the project StratoClim (grant agreement no. 603557).

The article processing charges for this open-access publication were covered by a Research

Centre of the Helmholtz Association.

Edited by: F. Fierli

\section{References}

Annamalai, H. and Slingo, J. M.: Active/break cycles: diagnosis of the intraseasonal variability of the Asian Summer Monsoon, Clim. Dynam., 18, 85-102, 2001.

Bannister, R. N., O'Neill, A., Gregory, A. R., and Nissen, K. M.: The role of the south-east Asian monsoon and other seasonal features in creating the "tape-recorder" signal in the Unified Model, Q. J. Roy. Meteor. Soc., 130, 1531-1554, 2004.
Bergman, J. W., Fierli, F., Jensen, E. J., Honomichl, S., and Pan, L. L.: Boundary layer sources for the Asian anticyclone: regional contributions to a vertical conduit, J. Geophys. Res., 118, 2560-2575, 2013.

Bergman, J. W., Pfister, L., and Yang, Q.: Identifying robust transport features of the upper tropical troposphere, J. Geophys. Res., 120, 6758-6776, 2015.

Bian, J., Pan, L. L., Paulik, L., Vömel, H., and Chen, H.: In situ water vapor and ozone measurements in Lhasa and Kunmin during the Asian summer monsoon, Geophys. Res. Lett., 39, L19808, doi:10.1029/2012GL052996, 2012.

Bourassa, A. E., Robock, A., Randel, W. J., Deshler, T., Rieger, L. A., Lloyd, N. D., Llewellyn, E. J. T., and Degenstein, D. A.: Large volcanic aerosol load in the stratosphere linked to Asian monsoon transport, Science, 337, 78-81, 2012.

Brasseur, G. and Solomon, S.: Aeronomy of the Middle Atmosphere: Chemistry and Physics of the Stratosphere and Mesosphere, 3rd Edn., Springer, Heidelberg, Germany, 2005.

Chen, B., Xu, X. D., Yang, S., and Zhao, T. L.: Climatological perspectives of air transport from atmospheric boundary layer to tropopause layer over Asian monsoon regions during boreal summer inferred from Lagrangian approach, Atmos. Chem. Phys., 12, 5827-5839, doi:10.5194/acp-12-5827-2012, 2012.

Dee, D. P., Uppala, S. M., Simmons, A. J., Berrisford, P., Poli, P., Kobayashi, S., Andrae, U., Balmaseda, M. A., Balsamo, G., Bauer, P., Bechtold, P., Beljaars, A. C. M., van de Berg, L., Bidlot, J., Bormann, N., Delsol, C., Dragani, R., Fuentes, M., Geer, A. J., Haimberger, L., Healy, S. B., Hersbach, H., Holm, E. V., Isaksen, L., Kallberg, P., Koehler, M., Matricardi, M., McNally, A. P., Monge-Sanz, B. M., Morcrette, J.-J., Park, B.-K., Peubey, C., de Rosnay, P., Tavolato, C., Thepaut, J.N., and Vitart, F.: The ERA-Interim reanalysis: configuration and performance of the data assimilation system, Q. J. Roy. Meteor. Soc., 137, 553-597, 2011.

Dethof, A., O’Neill, A., Slingo, J. M., and Smit, H. G. J.: A mechanism for moistening the lower stratosphere involving the Asian summer monsoon, Q. J. Roy. Meteor. Soc., 556, 1079-1106, 1999.

Dvortsov, V. L. and Solomon, S.: Response of the stratospheric temperatures and ozone to past and future increases in stratospheric humidity, J. Geophys. Res., 106, 7505-7514, 2001.

Fadnavis, S., Semeniuk, K., Pozzoli, L., Schultz, M. G., Ghude, S. D., Das, S., and Kakatkar, R.: Transport of aerosols into the UTLS and their impact on the Asian monsoon region as seen in a global model simulation, Atmos. Chem. Phys., 13, 8771-8786, doi:10.5194/acp-13-8771-2013, 2013.

Fadnavis, S., Schultz, M. G., Semeniuk, K., Mahajan, A. S., Pozzoli, L., Sonbawne, S., Ghude, S. D., Kiefer, M., and Eckert, E.: Trends in peroxyacetyl nitrate (PAN) in the upper troposphere and lower stratosphere over southern Asia during the summer monsoon season: regional impacts, Atmos. Chem. Phys., 14, 12725-12743, doi:10.5194/acp-14-12725-2014, 2014.

Fairlie, T. D., Vernier, J.-P., Natarajan, M., and Bedka, K. M.: Dispersion of the Nabro volcanic plume and its relation to the Asian summer monsoon, Atmos. Chem. Phys., 14, 7045-7057, doi:10.5194/acp-14-7045-2014, 2014.

Forster, P. and Shine, K. P.: Stratospheric water vapour change as possible contributor to observed stratospheric cooling, Geophys. Res. Lett., 26, 3309-3312, 1999. 
Forster, P. and Shine, K. P.: Assessing the climate impact of trends in stratospheric water vapor, Geophys. Res. Lett., 29, 10-1-10-4, 2002.

Fromm, M., Kablick III, G., Nedoluha, G., Carboni, E., Grainger, R., Campbell, J., and Lewis, J.: Correcting the record of volcanic stratospheric aerosol impact: Nabro and Sarychev Peak, J. Geophys. Res., 119, 10343-10364, 2014.

Garny, H. and Randel, W. J.: Dynamic variability of the Asian monsoon anticyclone observed in potential vorticity and correlations with tracer distributions, J. Geophys. Res., 118, 13421-13433, 2013.

Gettelman, A., Kinnison, D., Dunkerton, T. J., and Brasseur, G. P.: Impact of monsoon circulations on the upper troposphere and lower stratosphere, J. Geophys. Res., 109, D22101, doi:10.1029/2004JD004878, 2004.

Goswami, B. N.: South Asian monsoon, in: Intraseasonal Variability in the Atmosphere-Ocean Climate System, 2nd edn., chap. 2, edited by: Lau, W. K. M. and Waliser, D. E., Springer-Verlag, Berlin, Heidelberg, 21-72, 2012.

Grooß, J.-U. and Müller, R.: Simulation of ozone loss in Arctic winter 2004/2005, Geophys. Res. Lett., 34, L05804, doi:10.1029/2006GL028901, 2007.

Grooß, J.-U., Konopka, P., and Müller, R.: Ozone chemistry during the 2002 Antarctic vortex split, J. Atmos. Sci., 62, 860-870, 2005.

Grooß, J.-U., Engel, I., Borrmann, S., Frey, W., Günther, G., Hoyle, C. R., Kivi, R., Luo, B. P., Molleker, S., Peter, T., Pitts, M. C., Schlager, H., Stiller, G., Vömel, H., Walker, K. A., and Müller, R.: Nitric acid trihydrate nucleation and denitrification in the Arctic stratosphere, Atmos. Chem. Phys., 14, 10551073, doi:10.5194/acp-14-1055-2014, 2014.

Günther, G., Müller, R., von Hobe, M., Stroh, F., Konopka, P., and Volk, C. M.: Quantification of transport across the boundary of the lower stratospheric vortex during Arctic winter 2002/2003, Atmos. Chem. Phys., 8, 3655-3670, doi:10.5194/acp-8-36552008, 2008.

Hegglin, M. I., and Tegtmeier, S. (Eds.): SPARC Data Initiative: Assessment of Stratospheric Trace Gas and Aerosol Climatologies from Satellite Limb Sounders, SPARC Report No. 7, in press, 2016.

Jackson, D. R., Driscoll, S. J., Highwood, E. J., Harries, J. E., and Russell III, J. M.: Troposphere to stratosphere transport at low latitudes as studies using HALOE observations of water vapor 1992-1997, Q. J. Roy. Meteor. Soc., 124, 169-192, 1998.

Kirk-Davidoff, D. B., Hintsa, E. J., Anderson, J. G., and Keith, D. W.: The effect of climate change on ozone depletion through changes in stratospheric water vapour, Nature, 402, 399401, 1999.

Konopka, P. and Pan, L. L.: On the mixing-driven formation of the Extratropical Transition Layer (ExTL), J. Geophys. Res., 117, D18301, doi:10.1029/2012JD017876, 2012.

Konopka, P., Grooß, J.-U., Günther, G., Ploeger, F., Pommrich, R., Müller, R., and Livesey, N.: Annual cycle of ozone at and above the tropical tropopause: observations versus simulations with the Chemical Lagrangian Model of the Stratosphere (CLaMS), Atmos. Chem. Phys., 10, 121-132, 2010,

http://www.atmos-chem-phys.net/10/121/2010/.

Konopka, P., Ploeger, F., and Müller, R.: Entropy- and static stability-based Lagrangian model grids, in: Geophysical Mono- graph Series: Lagrangian Modeling of the Atmosphere, edited by Lin, J., vol. 200, pp. 99-109, American Geophysical Union, doi:10.1029/2012GM001253, 2012.

Kumar, K. K., Rajagopalan, B., Hoerling, M., Bates, G., and Cane, M.: Unraveling the Mystery of Indian Monsoon Failure During El Niño, Science, 314, 115-119, 2006.

Li, Q., Jiang, J. H., Wu, D. L., Read, W. G., Livesey, N. J., Waters, J. W., Zhang, Y., Wang, B., Filipiak, M. J., Davis, C. P., Turquety, S., Wu, S., Park, R. J., Yantosca, R. M., and Jacob, D. J.: Convective outflow of South Asian pollution: a global CTM simulation compared with EOS MLS observations, Geophys. Res. Lett., 32, L14826, doi:10.1029/2005GL022762, 2005.

Liu, Y., Wang, Y., Liu, X., Cai, Z., and Chance, K.: Tibetan middle tropospheric ozone minimum in June discovered from GOME observations, Geophys. Res. Lett., 36, L05814, doi:10.1029/2008GL037056, 2009.

Livesey, N. J., Filipiak, M. J., Froidevaux, L., Read, W. G., Lambert, A., Santee, M. L., Jiang, J. H., Pumphrey, H. C., Waters, J. W., Cofield, R. E., Cuddy, D. T., Daffer, W. H., Drouin, B. J., Fuller, R. A., Jarnot, R. F., Jiang, Y. B., Knosp, B. W., Li, Q. B., Perun, V. S., Schwartz, M. J., Snyder, W. V., Stek, P. C., Thurstans, R. P., Wagner, P. A., Avery, M., Browell, E. V., Cammas, J.-P., Christensen, L. E., Diskin, G. S., Gao, R.-S., Jost, H.-J., Loewenstein, M., Lopez, J. D., Nedelec, P., Osterman, G. B., Sachse, G. W., and Webster, C. R.: Validation of Aura Microwave Limb Sounder $\mathrm{O}_{3}$ and $\mathrm{CO}$ observations in the upper troposphere and lower stratosphere, J. Geophys. Res., 113, D15S02, doi:10.1029/2007JD008805, 2008.

Livesey, N. J., Read, W. G., Froidevaux, L., Lambert, A., Manney, G. L., Pumphrey, H. C., Santee, M. L., Schwartz, M. J., Wang, S., Cofield, R. E., Cuddy, D. T., Fuller, R. A., Jarnot, R. F., Jiang, J. H., Knosp, B. W., Stek, P. C., Wagner, P. A., , and Wu, D. L.: EOS MLS Version 3.3 Level 2 data quality and description document, Tech. rep., Jet Propulsion Laboratory, available from https: //mls.jpl.nasa.gov/data/v3-3_data_quality_document.pdf, 2011.

McKenna, D. S., Grooß, J.-U., Günther, G., Konopka, P., Müller, R., Carver, G., and Sasano, Y.: A new Chemical Lagrangian Model of the Stratosphere (CLaMS): 2. Formulation of chemistry scheme and initialization, J. Geophys. Res., 107, 4256, doi:10.1029/2000JD000113, 2002a.

McKenna, D. S., Konopka, P., Grooß, J.-U., Günther, G., Müller, R., Spang, R., Offermann, D., and Orsolini, Y.: A new Chemical Lagrangian Model of the Stratosphere (CLaMS): 1. Formulation of advection and mixing, J. Geophys. Res., 107, 4309, doi:10.1029/2000JD000114, 2002b.

Orbe, C., Waugh, D. W., and Newman, P. A.: Air-mass origin in the tropical lower stratosphere: The influence of Asian boundary layer air, Geophys. Res. Lett., 42, 4240-4248, 2015.

Pan, L. L., Konopka, P., and Browell, E. V.: Observations and model simulations of mixing near the extratropical tropopause, J. Geophys. Res., 111, D05106, doi:10.1029/2005JD006480, 2006.

Park, M., Randel, W. J., Kinnison, D. E., Garcia, R. R., and Choi, W.: Seasonal variation of methane, water vapor, and nitrogen oxides near the tropopause: Satellite observations and model simulations, J. Geophys. Res., 109, D03302, doi:10.1029/2003JD003706, 2004.

Park, M., Randel, W. J., Gettleman, A., Massie, S. T., and Jiang, J. H.: Transport above the Asian summer monsoon anticyclone 
inferred from Aura Microwave Limb Sounder tracers, J. Geophys. Res., 112, D16309, doi:10.1029/2006JD008294, 2007.

Park, M., Randel, W. J., Emmons, L. K., Bernath, P. F., Walker, K. A., and Boone, C. D.: Chemical isolation in the Asian monsoon anticyclone observed in Atmospheric Chemistry Experiment (ACE-FTS) data, Atmos. Chem. Phys., 8, 757-764, doi:10.5194/acp-8-757-2008, 2008.

Park, M., Randel, W. J., Emmons, L. K., and Livesey, N. J.: Transport pathways of carbon monoxide in the Asian summer monsoon diagnosed from Model of Ozone and Related Tracers (MOZART), J. Geophys. Res., 114, D08303, doi:10.1029/2008JD010621, 2009.

Ploeger, F., Konopka, P., Günther, G., Grooß, J.-U., and Müller, R.: Impact of the vertical velocity scheme on modeling transport across the tropical tropopause layer, J. Geophys. Res., 115, D03301, doi:10.1029/2009JD012023, 2010.

Ploeger, F., Günther, G., Konopka, P., Fueglistaler, S., Müller, R., Hoppe, C., Kunz, A., Spang, R., Grooß, J.-U., and Riese, M.: Horizontal water vapor transport in the lower stratosphere from subtropics to high latitudes during boreal summer, J. Geophys. Res., 118, 8111-8127, 2013.

Ploeger, F., Gottschling, C., Grießbach, S., Grooß, J.-U., Günther, G., Konopka, P., Müller, R., Riese, M., Stroh, F., Ungermann, J., Vogel, B., and von Hobe, M.: On deducing the transport barrier in the Asian summer monsoon anticyclone based on isentropic PV-gradients, Atmos. Chem. Phys., 15, 13145-13159, doi:10.5194/acp-15-13145-2015, 2015.

Pommrich, R., Müller, R., Grooß, J.-U., Konopka, P., Ploeger, F., Vogel, B., Tao, M., Hoppe, C. M., Günther, G., Spelten, N., Hoffmann, L., Pumphrey, H.-C., Viciani, S., D’Amato, F., Volk, C. M., Hoor, P., Schlager, H., and Riese, M.: Tropical troposphere to stratosphere transport of carbon monoxide and long-lived trace species in the Chemical Lagrangian Model of the Stratosphere (CLaMS), Geosci. Model Dev., 7, 2895-2916, doi:10.5194/gmd-7-2895-2014, 2014.

Randel, W. J. and Park, M.: Deep convective influence on the Asian summer monsoon anticyclone and associated tracer variability observed with Atmospheric Infrared Sounder (AIRS), J. Geophys. Res., 111, D12314, doi:10.1029/2005JD006490, 2006.

Randel, W. J., Park, M., Emmons, L., Kinnison, D., Bernath, P., Walker, K. A., Boone, C., and Pumphrey, H.: Asian monsoon transport of pollution to the stratosphere, Science, 328, 611-613, doi:10.1126/science.1182274, 2010.

Riese, M., Ploeger, F., Rap, A., Vogel, B., Konopka, P., Dameris, M., and Forster, P.: Impact of uncertainties in atmospheric mixing on simulated UTLS composition and related radiative effects, J. Geophys. Res., 117, D16305, doi:10.1029/2012JD017751, 2012.

Rosenlof, K. H., Tuck, A. F., Kelly, K. K., Russell III, J. M., and McCormick, M. P.: Hemispheric asymmetries in the water vapor and inferences about transport in the lower stratosphere, J. Geophys. Res., 102, 13213-13234, 1997.

Sander, S. P., Friedl, R. R., Barker, J. R., Golden, D. M., Kurylo, M. J., Wine, P. H., Abbatt, J. P. D., Burkholder, J. B., Kolb, C. E., Moortgat, G. K., Huie, R. E., and Orkin, V. L.: Chemical Kinetics and Photochemical Data for Use in Atmospheric Studies, JPL Publication, 10-6, 2011.

Schwartz, M. J., Manney, G. L., Hegglin, M. I., Livesey, N. J., Santee, M. L., and Daffer, W. H.: Climatology and variability of trace gases in extratropical double-tropopause regions from MLS, HIRDLS and ACE-FTS measurements, J. Geophys. Res., 120, 843-867, doi:10.1002/2014JD021964, 2015.

Shindell, D. T.: Climate and ozone response to increased stratospheric water vapor, Geophys. Res. Lett., 28, 1551-1554, 2001.

Smith, C. A., Haigh, J. D., and Toumi, R.: Radiative forcing due to trends in stratospheric water vapour, Geophys. Res. Lett., 28, 179-182, 2001.

Solomon, S., Rosenlof, K., Portmann, R., Daniel, J., Davis, S., Sanford, T., and Plattner, G.-K.: Contributions of stratospheric water vapor to decadal changes in the rate of global warming, Science, 327, 1219-1223, 2010.

Uma, K. N., Das, S. K., and Das, S. S.: A climatological perspective of water vapor at the UTLS region over different global monsoon regions: observations inferred from the Aura-MLS and reanalysis data, Clim. Dynam., 43, 407-420, 2014.

Vernier, J.-P., Thomason, L. W., and Kar, J.: CALIPSO detection of an Asian tropopause aerosol layer, Geophys. Res. Lett., 38, L07804, doi:10.1029/2010GL046614, 2011.

Vogel, B., Konopka, P., Grooß, J.-U., Müller, R., Funke, B., LópezPuertas, M., Reddmann, T., Stiller, G., von Clarmann, T., and Riese, M.: Model simulations of stratospheric ozone loss caused by enhanced mesospheric $\mathrm{NO}_{\mathrm{x}}$ during Arctic Winter 2003/2004, Atmos. Chem. Phys., 8, 5279-5293, doi:10.5194/acp-8-52792008, 2008.

Vogel, B., Feck, T., and Grooß, J.-U.: Impact of stratospheric water vapor enhancements caused by $\mathrm{CH}_{4}$ and $\mathrm{H}_{2}$ increase on polar ozone loss, J. Geophys. Res., 116, D05301, doi:10.1029/2010JD014234, 2011a.

Vogel, B., Pan, L. L., Konopka, P., Günther, G., Müller, R., Hall, W., Campos, T., Pollack, I., Weinheimer, A., Wei, J., Atlas, E. L., and Bowman, K. P.: Transport pathways and signatures of mixing in the extratropical tropopause region derived from Lagrangian model simulations, J. Geophys. Res., 116, D05306, doi:10.1029/2010JD014876, 2011b.

Vogel, B., Feck, T., Grooß, J.-U., and Riese, M.: Impact of a possible future global hydrogen economy on Arctic stratospheric ozone loss, Energ. Environ. Sci., 5, 6445-6452, 2012.

Vogel, B., Günther, G., Müller, R., Grooß, J.-U., Hoor, P., Krämer, M., Müller, S., Zahn, A., and Riese, M.: Fast transport from Southeast Asia boundary layer sources to northern Europe: rapid uplift in typhoons and eastward eddy shedding of the Asian monsoon anticyclone, Atmos. Chem. Phys., 14, 12745-12762, doi:10.5194/acp-14-12745-2014, 2014.

Webster, P. J., Magaña, V. O., Palmer, T. N., Shukla, J., Tomas, R. A., Yanai, M., and Yasunari, T.: Monsoon: Processes, predictability, and the prospects for prediction, J. Geophys. Res., 103, 14.451-14.510, 1998.

Xiong, X., Houweling, S., Wei, J., Maddy, E., Sun, F., and Barnet, C.: Methane plume over south Asia during the monsoon season: satellite observation and model simulation, Atmos. Chem. Phys., 9, 783-794, doi:10.5194/acp-9-783-2009, 2009. 